\title{
Induced Pluripotent Stem Cell-Derived Podocyte-Like Cells as Models for Assessing Mechanisms Underlying Heritable Disease Phenotype: Initial Studies Using Two Alport Syndrome Patient Lines Indicate Impaired Potassium Channel Activity
}

\author{
John M. Haynes, James N. Selby, Teresa H. Vandekolk, Isaiah P. L. Abad, Joan K. Ho, \\ Wai-Ling Lieuw, Katie Leach, Judith Savige, Sheetal Saini, Craig L. Fisher, \\ and Sharon D. Ricardo
}

Monash Institute of Pharmaceutical Sciences (J.M.H., J.N.S., T.H.V., I.P.L.A., J.K.H., W.-L.L., K.L.) and Department of Anatomy and Developmental Biology (S.S., C.L.F., S.D.R.), Monash University, Victoria, Australia; and Department of Medicine, Royal Melbourne Hospital, Victoria, Australia (J.S.)

Received April 23, 2018; accepted July 26, 2018

\begin{abstract}
Renal podocyte survival depends upon the dynamic regulation of a complex cell architecture that links the glomerular basement membrane to integrins, ion channels, and receptors. Alport syndrome is a heritable chronic kidney disease where mutations in $\alpha 3, \alpha 4$, or $\alpha 5$ collagen genes promote podocyte death. In rodent models of renal failure, activation of the calcium-sensing receptor (CaSR) can protect podocytes from stress-related death. In this study, we assessed CaSR function in podocyte-like cells derived from induced-pluripotent stem cells from two patients with Alport Syndrome (AS1 \& AS2) and a renal disease free individual [normal human mesangial cell (NHMC)], as well as a human immortalized podocyte-like (HIP) cell line. Extracellular calcium elicited concentration-dependent elevations of intracellular calcium in all podocyte-like cells. NHMC and HIP, but not AS1 or AS2 podocyte-like cells, also showed acute reductions in
\end{abstract}

intracellular calcium prior to elevation. In NHMC podocyte-like cells this acute reduction was blocked by the large-conductance potassium channel (KCNMA1) inhibitors iberiotoxin (10 nM) and tetraethylammonium $(5 \mathrm{mM})$, as well as the focal adhesion kinase inhibitor PF562271 (N-methyl-N-(3-((2-(2-oxo-2,3-dihydro-1H-indol5-ylamino)-5-trifluoromethyl-pyrimidin-4-ylamino)-methyl)-pyridin2-yl)-methanesulfonamide, $10 \mathrm{nM}$ ). Quantitative polymerase chain reaction (qPCR) and immunolabeling showed the presence of KCNMA1 transcript and protein in all podocyte-like cells tested. Cultivation of AS1 podocytes on decellularized plates of NHMC podocyte-like cells partially restored acute reductions in intracellular calcium in response to extracellular calcium. We conclude that the AS patient-derived podocyte-like cells used in this study showed dysfunctional integrin signaling and potassium channel function, which may contribute to podocyte death seen in Alport syndrome.

\section{Introduction}

Podocytes regulate renal filtration through slit diaphragmsmodified adherens junctions that span the 30 - to 50-nm-wide gaps between foot processes with a zipper-like pattern of transmembrane proteins, including nephrin and fatty acid transporter tumor suppressor homolog and P-cadherin (Reiser et al., 2000). At the cytoplasmic surface, the slit

This work was supported by the Alport Foundation of Australia, the Alport Syndrome Foundation and the Kidney Foundation of Canada.

https://doi.org/10.1124/jpet.118.250142. diaphragm contains dense regions of Triton-X-resistant material (Mundel and Kriz, 1995), which acts as a signaling hub for downstream regulators of integrin activity, such as focal adhesion kinase (Blattner and Kretzler, 2005), as well as ion channels and G-protein-coupled receptors (Greka and Mundel, 2012)

Chronic kidney disease may arise secondary to other diseases, such as diabetes, or less commonly through mutations of genes essential for normal kidney function, such as $\alpha$-actinin-4 (Obeidová et al., 2006) or collagen IV (Feingold et al., 1985). Alport syndrome (AS) is a genetic condition associated with progressive loss of kidney function as well as hearing loss and

ABBREVIATIONS: AS, Alport syndrome; ANOVA, analysis of variance; 4-Br-A23187, 6-bromo-5-(methylamino)-2-[[(2S,3R,5R,6S,8R,9R)-3,5,9trimethyl-2-[(2S)-1-oxo-1-(1H-pyrrol-2-yl)propan-2-yl]-1,7-dioxaspiro[5.5]undecan-8-yl]methyl]-1,3-benzoxazole-4-carboxylic acid; [Ca $\left.{ }^{2+}\right]_{i}$, intracellular calcium; $\left[\mathrm{Ca}^{2+}\right]_{0}$, extracellular calcium; CaSR, calcium-sensing receptor; DMEM, Dulbecco's modified Eagle's medium; FAK, focal adhesion kinase; $\mathrm{Gd}^{3+}$, gadolinium; HIP, human immortalized podocyte-like; iPS, induced pluripotent stem cell; KCNMA1, large-conductance potassium channel; MEF, mouse embryonic fibroblast; NHMC, normal human mesangial cell; NS1619, 1-(2'-hydroxy-5'-trifluoromethylphenyl)-5trifluoromethyl-2(3H)-benzimidazolone; PD123,319, 3-[2,13,18-tris(2-amino-2-oxoethyl)-12,17-bis(3-amino-3-oxopropyl)-3-[3-(2-hydroxypropylamino)3-oxopropyl]-3,5,8,8,13,15,18,19-octamethyl-1,2,5,6,7,10,12,17-octahydrocorrin-7-yl]propanamide; PF562271, N-methyl-N-(3-((2-(2-oxo-2,3-dihydro-1Hindol-5-ylamino)-5-trifluoromethyl-pyrimidin-4-ylamino)-methyl)-pyridin-2-yl)-methanesulfonamide; qPCR, quantitative polymerase chain reaction; TEA, tetraethylammonium; WT-1, Wilm's tumor-1. 
eye abnormalities. Individuals with AS have mutations in the COL $4 A 3, C O L 4 A 4$, or COL $4 A 5$ collagen genes, resulting in the absence of $\alpha 3 \alpha 4 \alpha 5$ collagen chains in the glomerular basement membrane. Ultimately, AS results in proteinuria and renal failure (Feingold et al., 1985; Barker et al., 1990; Mochizuki et al., 1994; Hudson et al., 2003; Cosgrove, 2012). Although the mechanisms underlying renal failure are unclear, evidence suggests that the translation of mutant $C O L 4 A 5 \mathrm{mRNA}$ results in a protein that is unable to interact with heat shock protein 47 , an endoplasmic reticulum protein that regulates appropriate protein folding (Ishida and Nagata, 2011). This is thought to lead to incorrectly folded protein accumulation in the endoplasmic reticulum and induction of the unfolded protein response (Pieri et al., 2014).

Although treatments for AS commonly rely on inhibition of effects of angiotensin II to promote podocyte survival, the activation of another G-protein-coupled receptor, the calciumsensing receptor (CaSR), has profound podocyte cytoskeletonstabilizing and prosurvival effects (Oh et al., 2011).

The paucity of treatments for chronic kidney diseases such as AS is, we believe, partly due to a lack of robust, in vitro model systems to study podocyte function in health and disease. Current model systems, such as primary cultures of human podocytes, only replicate for a short time and cannot be maintained over long periods (Shankland et al., 2007). Alternatively, immortalizing podocytes has enabled the production of large numbers of podocyte-like cells; however, the process of immortalization reduces their suitability for toxicological screening applications and may introduce changes in phenotype that are not immediately obvious. Recently, we used induced pluripotent stem cells (iPS) derived from normal human mesangial cells (NHMCs) to generate podocyte-like cells that express the morphologic and genetic characteristics of human podocytes (Song et al., 2011, 2012). The current study extended this work to produce two new AS patient-derived iPS cell lines (AS1 and AS2). Given the contributions of the CaSR (Ogata et al., 2003; Oh et al., 2011) and angiotensin II (Liebau et al., 2006) receptor subtypes to podocyte function and survival, we now use activators of these receptor signaling systems to compare the functional activities of AS and NHMC podocyte-like cells against commonly used human immortalized podocyte-like (HIP) cells (Saleem et al., 2002). We demonstrate that AS patient-derived podocyte-like cells show a distinct pattern of response to the addition of activators of the CaSR. In NHMC and HIP cells, but not AS podocyte-like cells, extracellular calcium-dependent elevations of intracellular calcium are preceded by acute reductions in intracellular calcium. The largeconductance calcium activated potassium channel (KCNMA1) opener NS1619 (1-(2' -hydroxy-5' -trifluoromethylphenyl)-5trifluoromethyl-2(3H)-benzimidazolone, Olesen et al., 1994) similarly reduced resting calcium in HIPs and NHMCs, but not AS podocyte-like cells. In contrast to functional analysis, KCNMA1 channel mRNA and immunolabeled protein were equally evident in both AS and NHMC podocyte-like cells. Replating AS1 podocytes onto decellularized NHMC podocytelike cell plates partially restored the acute reductions in intracellular calcium. We conclude that the two AS patient-derived podocyte-like cell lines generated herein showed a loss of large KCNMA1 channel activity, and we speculate that the loss of function of these channels is due to inappropriate collagen-integrin interactions.

\section{Materials and Methods}

Derivation of iPS Cells from AS Patients. These studies were carried out in accordance with the Declaration of Helsinki and approved by the Northern Health Human Research Ethics Committee. Fibroblasts from unrelated male patients with X-linked AS due to COL4A5 missense mutations [p.G908R (AS1) or p.G624D (AS2)] were collected via biopsy. AS1 male mutation phenotype was severe, with early-onset renal failure at age 14 years as well as hearing loss, lenticonus, and central fleck retinopathy. The AS2 male had renal failure onset at age 54 years, with hearing loss and no lenticonus but had central retinopathy (a much milder clinical phenotype). After skin biopsy, patient fibroblasts were cultivated in Dulbecco's modified Eagle's medium (DMEM; Invitrogen, Melbourne, Australia) with $10 \%$ fetal bovine serum (Invitrogen), 1\% penicillin/streptomycin (Invitrogen), and 1\% L-glutamine (Invitrogen) at $37^{\circ} \mathrm{C}$ prior to reprogramming. Figure $1 \mathrm{~A}$ shows typical immunolabeling for fibroblast desmin. Skin biopsy-derived dermal fibroblasts were plated in a 12-well plate (Falcon Corning, Mulgrave, Australia) at a range of densities including 12,500, 25,000, 50,000 , and 100,000 cells/well in duplicate. The plate was incubated for 2 days at $37^{\circ} \mathrm{C}$ and $5 \% \mathrm{CO}_{2}$. At $80 \%$ confluence, one well was selected for reprogramming based on viable appearance and cell density, the directions of the CytoTune-iPS 2.0 Sendai Reprogramming Kit (Thermo Fisher Scientific, Waltham, MA) were applied for reprogramming, and resultant cells were plated on a 1-million-cell mouse embryonic fibroblast (MEF) feeder layer. Once colony formation was observed at 2-3 weeks post induction, colonies were mechanically passaged using a 26-gauge needle onto a new MEF layer. After reprogramming, iPS cultures were maintained on an MEF feeder layer in media [DMEM/F12 medium, GLUTAMAX, Knockout Serum Replacement, Non-essential Amino Acid (all from ThermoFisher, Scorseby, Autralia), and $10 \mathrm{ng} / \mathrm{ml}$ basic fibroblast growth factor (Merck Millipore, Burlington, MA)]. Medium was changed once daily for optimal cell growth/survival (Fig. 1B shows colonies expressing alkaline phosphatase activity). At this stage, the colonies displayed a normal karyotype (Fig. 1C).

Differentiation of iPS Cells to Podocyte Progenitors. iPS colonies were cut into small pieces, and the cells were transferred into MEF-coated organ culture dishes for 7 days prior to characterization studies. To initiate differentiation, iPS cell colonies were mechanically cut into pieces and cultured in Geltrex-coated (ThermoFisher, Scorseby, Australia) plates containing DMEM/F12 (Sigma-Aldrich, Castle Hill, Australia) supplemented with $2.5 \%$ fetal bovine serum, $1 \%$ nonessential amino acids, and $100 \mu \mathrm{M} \beta$-mercaptoethanol, with $10 \mathrm{ng} / \mathrm{ml}$ activin A, $15 \mathrm{ng} / \mathrm{ml} \mathrm{BMP7,} \mathrm{and} 0.1 \mu \mathrm{M}$ retinoic acid (Life Technologies). To assess differentiation capacity, undifferentiated iPS cells were transplanted under the kidney capsule of immune-incompetent mice for 3 months, where they formed cyst-like structures (Fig. 1D). Figure 1, panel E, shows an overview of the podocyte differentiation protocol. Within the cyst-like structures, H\&E staining showed the formation of crude glomerulus-like structures (Fig. 1, F and G). For differentiation, cells were replated at day 4 and permitted a further 6 days of directed differentiation, and the iPS-derived podocytes were grown for a further 10 days in DMEM/F12 without the activin A, $\mathrm{BMP} 7$, or retinoic acid and were able to maintain their morphology and functional characteristics (Song et al., 2012). By day 10, colonies demonstrated a characteristic "cobblestone" morphology (Fig. 1H). By day 20, podocyte-like cells exhibited the characteristic morphology of two-dimensional cultured podocytes, i.e., large cells with intracytoplasmic extensions (Kabgani et al., 2012) (Fig 1I). Our previous studies showed that this differentiation protocol markedly increases transcript and/or protein levels for podocin, synaptopodin, Wilm's tumor-1 (WT-1), Pax2 and nephrin at comparable levels to primary human podocytes (Song et al., 2012). Furthermore, podocytes differentiated using this protocol were able to successfully integrate into developing kidneys (Song et al., 2012). The key aspect of this previous work is that immunolabeling showed that large cells with intracytoplasmic extensions were immunoreactive for podocin, synaptopodin, and WT-1 (see Figs. 2 and 9 as exemplars of the morphologically distinct 

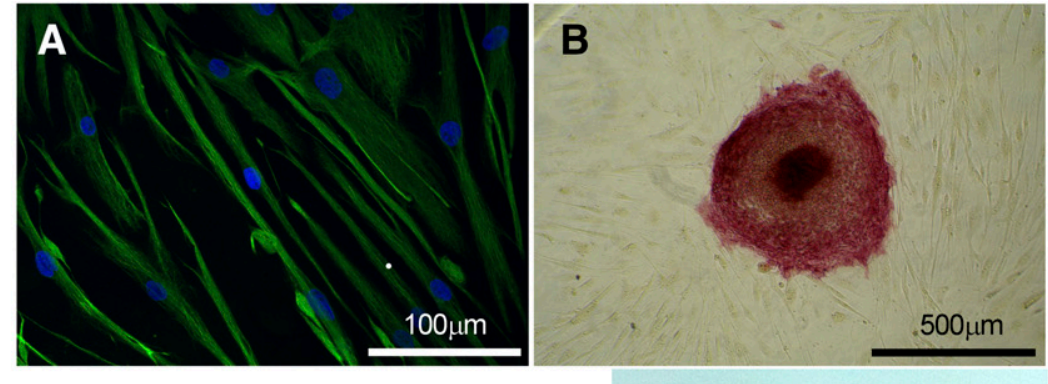

\section{C}
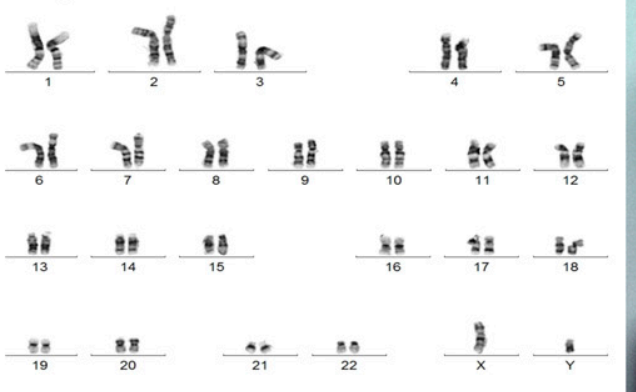

$$
\text { E }
$$

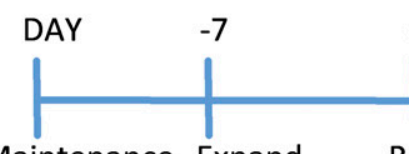

Maintenance Expand

\begin{tabular}{|c|c|c|c|c|}
\hline Cell Type & $\begin{array}{c}\text { iPS cell } \\
\text { colony }\end{array}$ & $\begin{array}{c}\text { iPS bulk } \\
\text { culture }\end{array}$ & \multicolumn{2}{|c|}{ iPS podocyte differentiation } \\
\hline Media & \multicolumn{2}{|c|}{ ES Media } & \multicolumn{2}{|c|}{ iPS-podocyte media } \\
\hline Additives & \multicolumn{2}{|c|}{ bFGF (10ng/ml) } & \multicolumn{1}{|c|}{$\begin{array}{c}\text { Activin A (10ng/ml) } \\
\text { BMP7 (15ng/ml) } \\
\text { Retinoic Acid (0.1uM) }\end{array}$} & \\
\hline $\begin{array}{c}\text { Growth } \\
\text { Condition }\end{array}$ & MEF layer & \multicolumn{3}{|c|}{$\begin{array}{c}\text { Geltrex } \\
\text { TM }\end{array}$} \\
\hline
\end{tabular}
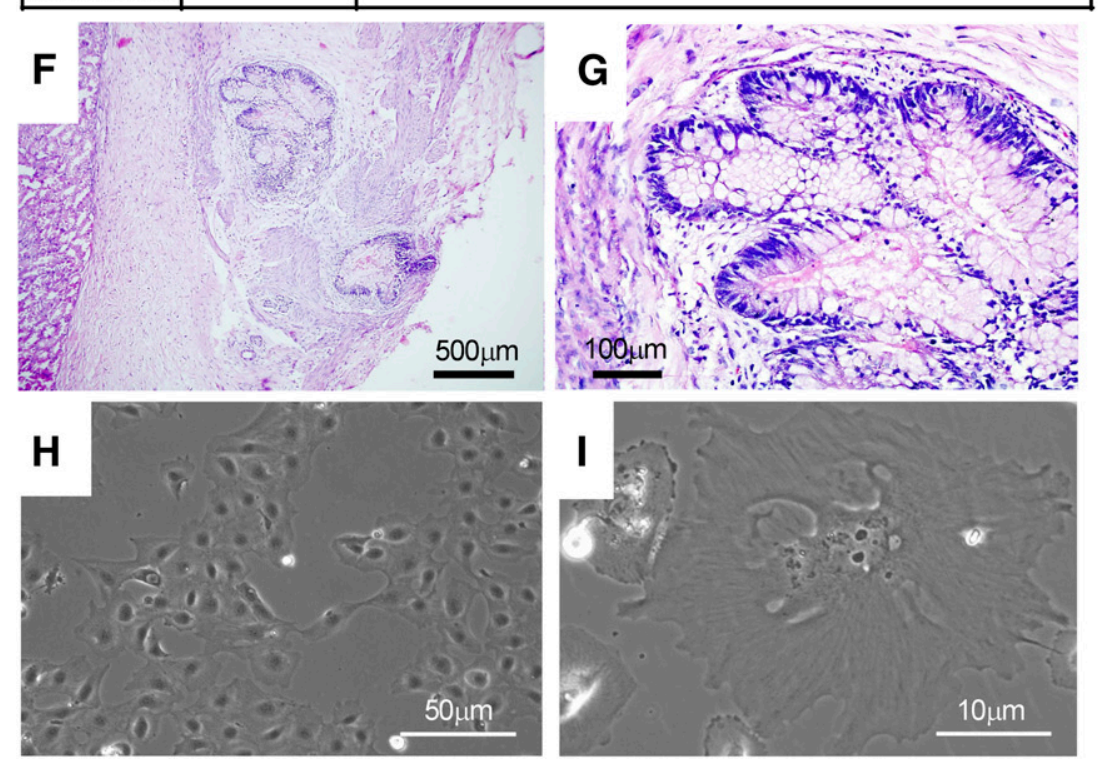

Fig. 1. Induced pluripotent stem cell-derived podocyte-like cells. (A) Dermal fibroblasts from AS patient, prior to reprogramming, immunolabeled for desmin (green) and DAPI (4',6-diamidino-2-phenylindole, blue). Low-power image of a colony expressing alkaline phosphatase activity (B) that expresses a normal karyotype (C). At day four of differentiation cells were replated or transplanted under the kidney capsule of immune-competent mice where they formed cyst like structures at day 20 (Figure 1, panel D, the scale bar shows mm divisions). Panel (E) provides an overview of the differentiation method for pluripotent stem cell derived podocyte-like cell differentiation. Within the cyst-like structures H\&E staining showed the formation of crude glomerulus-like structures (Figure 1, panels $\mathrm{F}$ and G). During development colonies demonstrated a characteristic epithelial cell "cobblestone" like morphology (Figure 1, panel H). At the time of use, podocyte-like cells exhibited the morphology of cultured podocytes, ie. large flat generally rounded cells with pronounced cytoskeleton (Figure 1, panel I). cell types that we select for imaging studies). Within the limitations of immunolabeling studies, we report no observable differences in podocyte-specific immunolabeling between AS1, AS2, and NHMC podocytes (not shown). At no stage did we see evidence that any of these differentiated podocyte-like cells were immunoreactive for the fibroblast marker desmin. 
HIP
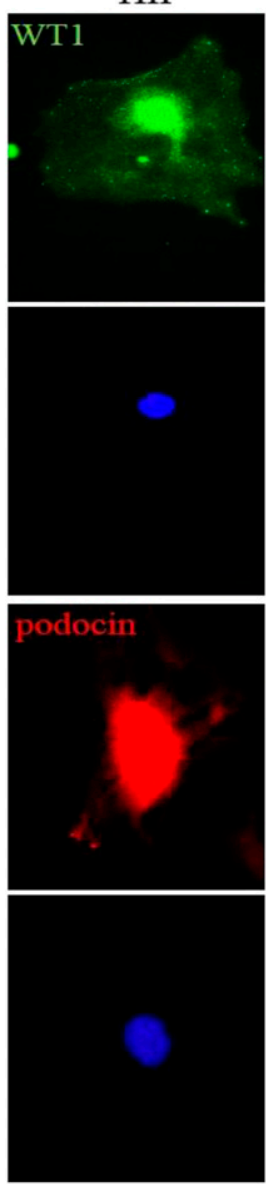

NHMC
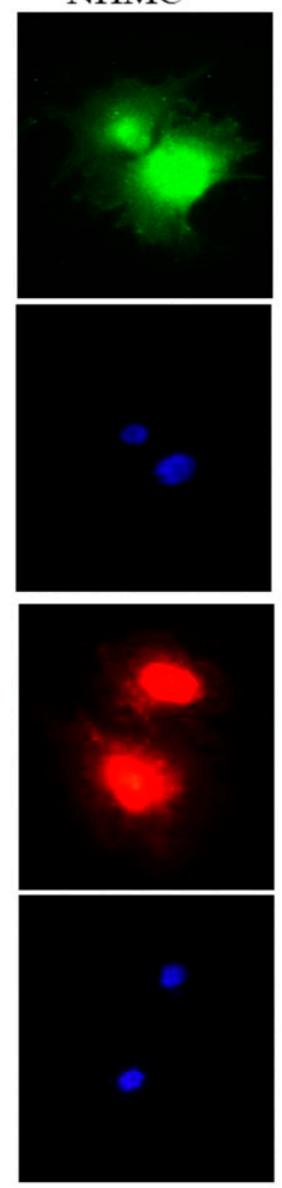

AS1
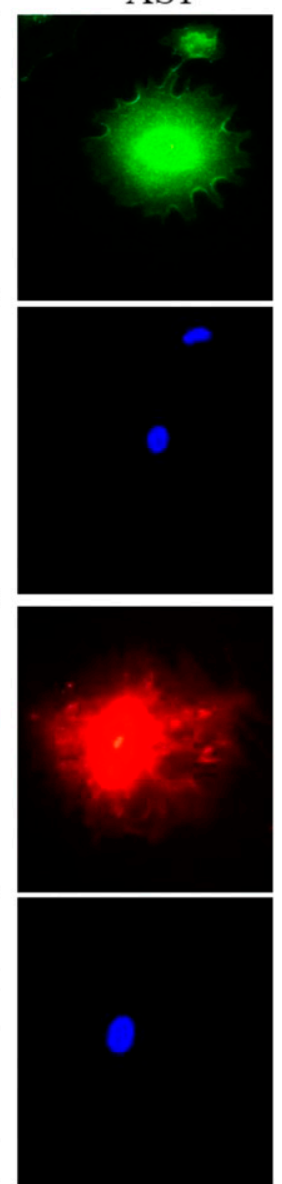

Fig. 2. Immunolabeling profiles of HIP, NHMC, and AS1 podocyte-like cells at day 20 of differentiation. Images show high-magnification images of single podocyte-like cells to confirm expression of podocyte markers: Wilms tumor-1 (WT-1) and podocin (nephrosis 2, idiopathic, steroidresistant protein). Images show representative cells from three different differentiations, except podocin in HIPs. Scale bar, $20 \mu \mathrm{m}$ (applicable to all images).

For functional studies, podocyte-like cells were seeded onto either six-well plates for quantitative polymerase chain reaction (qPCR) or glass-bottomed 35-mm dishes (MatTek, Ashland, MA) for calcium imaging and used at days 20-25 of differentiation (Fig. 1I).

Cell Culture of Immortalized Podocytes. Human, SV40-T transformed podocytes (Saleem et al., 2002) (HIPs) were routinely cultured at $33^{\circ} \mathrm{C}$ in RPMI 1640 medium with penicillin/streptomycin, insulin, transferrin, selenite, and $10 \%$ fetal calf serum. Following splitting, these cells were incubated in the presence of $2 \%$ fetal calf serum at $37^{\circ} \mathrm{C}$ for 2 weeks to reduce proliferation and promote differentiation prior to use.

Calcium Imaging. Calcium imaging studies were undertaken using a modification of a previously published protocol (Watmuff et al., 2015). In brief, podocyte-like cells were loaded with FURA-2 AM or Fluo4-AM (10 $\mu \mathrm{M}$; Molecular Probes, Eugene, OR) for 30 minutes at $37^{\circ} \mathrm{C}$. All experiments were performed in buffer (of the following composition: $145 \mathrm{mM} \mathrm{NaCl}, 1 \mathrm{mM} \mathrm{MgSO} 4,5 \mathrm{mM} \mathrm{KCl}, 10 \mathrm{mM}$ glucose, and $10 \mathrm{mM}$ HEPES) containing $0.1 \%$ bovine serum albumin (w/v), $\mathrm{pH}$ 7.4. Depending upon the experimental protocol, the buffer contained $0,0.2$, or $2 \mathrm{mM}$ or $0,0.02,0.2,2$, and $20 \mathrm{mM}$ calcium chloride. A heated stage kept cells at $37^{\circ} \mathrm{C}$ while they were viewed with a Nikon Eclipse TE2000E microscope (Nikon, Tokyo, Japan) at $10 \times$ magnification. Within each field of view, $5-10$ podocyte-like cells were chosen and analysis regions were drawn within each cell.
For FURA-2 AM imaging, cells were illuminated alternately with 340/26- and 387/11-nm light for $500 \mathrm{~ms}$ in a 1.5-second cycle. Emission was captured at $520 / 20 \mathrm{~nm}$ using a SPOT-RT camera (Diagnostic Instruments, Sterling Heights, Michigan, USA) controlled by MetaFluor imaging software (v6.lr5; Universal Imaging, Bedford Hills, NY). Background emission values from excitation wavelengths (measured in a cell-free region) were subtracted from each image. The resultant emission values were expressed as an emission ratio $(340: 380 \mathrm{~nm})$. All podocyte-like cells were allowed a 15 - to 20 -minute equilibration period prior to agonist addition.

Cumulative concentration-response curves and vehicle (buffer) responses were generated by the addition of calcium $\left(\mathrm{CaCl}_{2}, 0.2-20 \mathrm{mM}\right.$ in calcium-free buffer) or angiotensin II $\left(0.3-300 \mathrm{nM}\right.$ in $2 \mathrm{mM} \mathrm{CaCl}_{2}$ buffer). For gadolinium and spermidine cumulative concentrationresponse curves, podocyte-like cells were incubated in buffer containing $0.2 \mathrm{mM}$ calcium throughout experimentation. Concentrations of vehicle (either buffer or $0.01 \%$ final concentration dimethylsulfoxide) were added to culture wells for 1-3 minutes before the addition of ligand. In some experiments, iberiotoxin [100 nM (Cook et al., 2002)], tetraethylammonium [TEA, $5 \mathrm{mM}$ (Lang et al., 2004)], focal adhesion kinase (FAK) inhibitor [N-methyl-N-(3-((2-(2-oxo-2,3-dihydro-1H-indol-5ylamino)-5-trifluoromethyl-pyrimidin-4-ylamino)-methyl)-pyridin-2-yl)methanesulfonamide, PF562271, $10 \mathrm{nM}$, approximately 7 times its $\mathrm{IC}_{50}$ for FAK and 0.7 times its $\mathrm{IC}_{50}$ for Pyk2 (Roberts et al., 2008)], or vehicle ( $0.01 \%$ dimethylsulfoxide) was added to cultures $10-15$ minutes prior to the addition of calcium chloride.

The KCNMA1 channel opener NS1619 (1-10 $\mu \mathrm{M})$ (Olesen et al., 1994) was added cumulatively at 10 -minute intervals.

To calculate ligand-induced elevations of intracellular calcium $\left(\left[\mathrm{Ca}^{2+}\right]_{\mathrm{i}}\right)$, peak responses were expressed as a fraction of the average (340:380) emission ratio over the 25-second period prior to the first addition of ligand or vehicle. To calculate ligand-induced reductions in $\left[\mathrm{Ca}^{2+}\right]_{\mathrm{i}}$, the postligand minimum response was expressed as a fraction of the average (340:380) emission ratio over the 25-second period immediately before each addition of ligand.

Cellular (nanomolar) calcium was calculated according to the method described by Preston and Haynes (2003) using the following equation: $\left[\mathrm{Ca}^{2+}\right]_{\mathrm{i}}=\mathrm{K}_{\mathrm{D}} \beta\left(\left(\mathrm{R}-\mathrm{R}_{\min }\right) /\left(\mathrm{R}_{\max }-\mathrm{R}\right)\right.$ ) (Grynkiewicz et al., 1985). $\beta$ Is the emission ratio, $R_{\min } / R_{\max }$, at $380 \mathrm{~nm}$. The $K_{D}$ value $(285 \mathrm{nM})$ was taken from Groden et al. (1991). The $R_{\min }$ value was obtained in the presence of both 4-Br-A23187 (6-bromo-5-(methylamino)-2[[(2S,3R,5R,6S,8R,9R)-3,5,9-trimethyl-2-[(2S)-1-oxo-1-(1H-pyrrol-2-yl) propan-2-yl]-1,7-dioxaspiro[5.5]undecan-8-yl]methyl]-1,3-benzoxazole4-carboxylic acid, $20 \mu \mathrm{M})$ and EGTA $(10 \mathrm{mM})$. The $\mathrm{R}_{\max }$ was obtained in the presence of 4-Br-A23187 $(20 \mu \mathrm{M})$ and $\mathrm{Ca}^{2+}(100 \mathrm{mM})$. Mean and $95 \%$ confidence interval data were calculated using $\log _{10}$ resting cytosolic $\left[\mathrm{Ca}^{2+}\right]_{\mathrm{i}}$ from each cell.

For AS1 replating experiments, cells were loaded with Fluo4-AM (10 $\mu \mathrm{M}, 30$ minutes) and placed onto the heated stage of a Nikon A1R confocal microscope and illuminated at $488 \mathrm{~nm}$ every second. Following equilibration (5-10 minutes), calcium chloride $(0,0.02,0.2,2$, or $20 \mathrm{mM}$ ) was added over a 20 -minute period. Nikon software was used to calculate emission intensity $(520 / 20 \mathrm{~nm})$ in regions within cells. For analysis, background fluorescence intensity was subtracted from each cellular region of interest. To calculate acute reductions in $\left[\mathrm{Ca}^{2+}\right]_{\mathrm{i}}$, the postligand minimum response was expressed as a fraction of the average fluorescence over the 25 -second period immediately before each addition of ligand.

Immunolabeling. Cells were processed as described previously (Song et al., 2012). In brief, cells were fixed with $4 \%$ paraformaldehyde and labeled with antipodocin, anti-WT-1, or anti-KCNMA1 antibodies ( $1 \mu \mathrm{g} / \mathrm{ml}, 24$ hours, $4^{\circ} \mathrm{C}$; Abcam, Melbourne, Australia) followed by Alexa Fluor 488 or Alexa Fluor 555 secondary antibodies (1:1000; Molecular Probes) for 2 hours at room temperature. Cells were counterstained with DAPI (4',6-diamidino-2-phenylindole 1:10,000; Life Technologies) or Alexa 567 conjugated phalloidin (1:1000; Molecular Probes) prior to visualization with a Nikon A1R microscope. 
Quantitative PCR. Quantitative PCR was undertaken using a method previously described (Watmuff et al., 2015). In brief, total RNA was extracted from $10^{6}$ cells using the Bioline RNA Mini Kit (Bioline, Alexandria, Australia) according to manufacturer's instructions. Samples were analyzed for RNA content using a Nanodrop ND-1000 (ThermoFisher) spectrophotometer. Reactions were performed in triplicate on samples aggregated from at least three independently differentiating wells using the Bioline Sensifast SYBR No-ROX One Step Kit according to the manufacturer's specifications. KCNMA1 forward primer was CCTGGCCTCCTCCATGGT (melting temperature: $60^{\circ} \mathrm{C}$ ) and reverse primer was TTCTGGGCCTCCTTCGTCT $\left(59^{\circ} \mathrm{C}\right)$. Relative gene expression was expressed as the ratio between target gene $\mathrm{Ct}$ values to $\beta$-actin Ct values.

Replating AS Podocyte-Like Cells onto Decellularized Plates that Had Contained NHMC Podocyte-Like Cells. Decellularized tissue scaffolds, where removal of living cells leaves behind a cellular matrix that can influence culture differentiation and/or cellular function, are commonly used in stem cell biology [for example, see Morissette Martin et al. (2018)]. We tested the idea that replating AS podocytes onto tissue culture plates that had contained NHMC cells could restore potassium channel function. Thus, we took tissue culture plates containing confluent monolayers of NHMC or AS1 podocyte-like cells and decellularized using the method of Baiguera et al. (2014): in brief, plates were frozen $\left(-80^{\circ} \mathrm{C}\right)$ and thawed four times, incubated with Milli-Q water (72 hours at room temperature), and then processed twice with $1.0 \%$ Triton X-100 (60 minutes), water (30 minutes), $4.0 \%$ deoxycholate (60 minutes), and water (30 minutes). After the last washing step, plates were washed with phosphatebuffered saline prior to addition of AS1 podocyte-like cells. To remove AS1 podocyte-like cells from culture plates, cells were incubated with TrypLE Select (ThermoFisher) prior to centrifugation (150g). Cells were resuspended in culture medium and plated onto tissue culture plates that had contained AS1 or NHMC podocyte-like cells. Five days later, the cells were used for Fluo-4 calcium imaging (as described earlier).

Statistical Analysis. Unless otherwise stated, results from experiments are presented as the mean \pm S.E.M. of at least three biologic replicate experiments. Statistical analysis was performed on raw data with one- or two-way analysis of variance (ANOVA) followed by post hoc Dunnett's test to show ligand effects versus vehicle response. All analyses were performed using PRISM v6.00 (GraphPad Software, La Jolla, CA). In all cases, a $P$ value less than 0.05 was considered significant. Graphs are shown with ligand effects expressed as a fraction of the response to the appropriate vehicle.

A
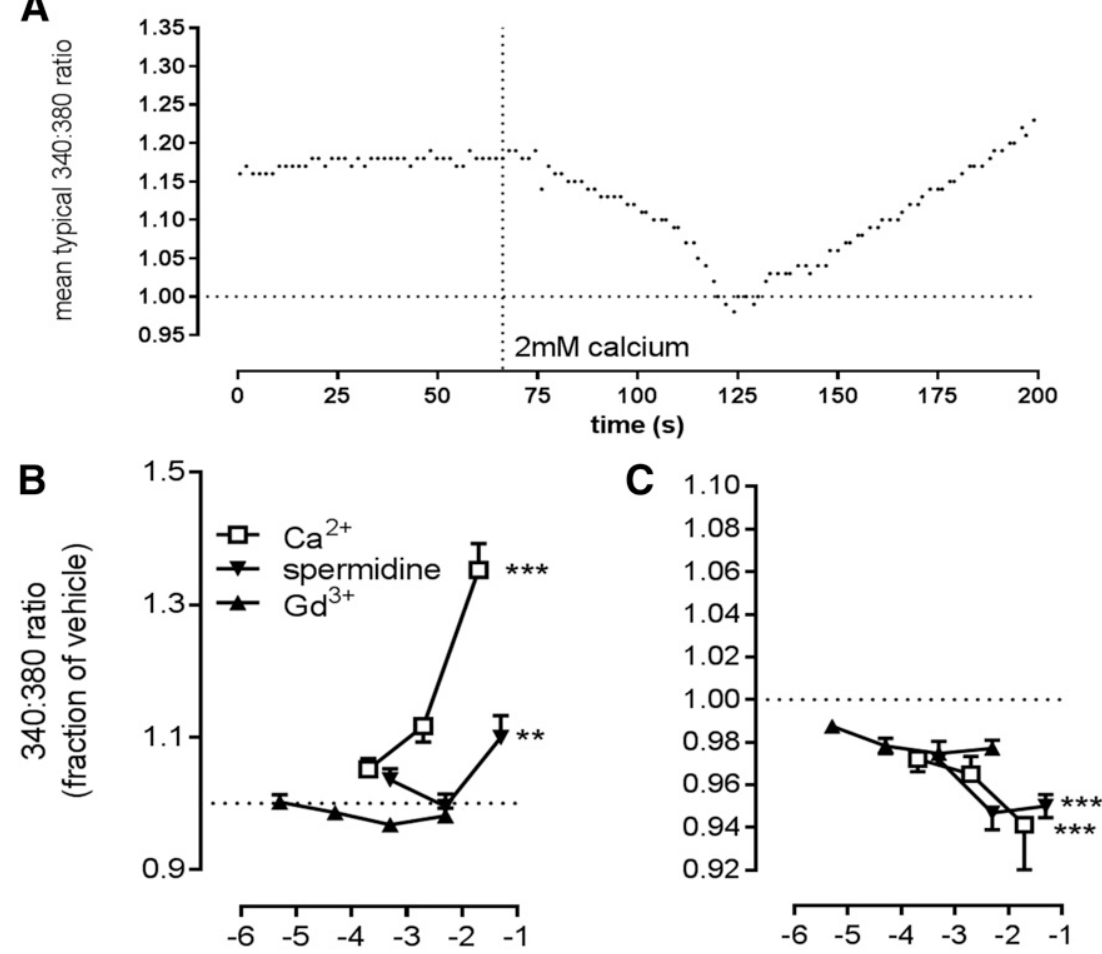

Fig. 3. Effects of $\left[\mathrm{Ca}^{2+}\right]_{o}$ on $\left[\mathrm{Ca}^{2+}\right]_{i}$ in FURA-2 AM-loaded human immortalized podocyte-like cells. (A) Typical effect of $2 \mathrm{mM}\left[\mathrm{Ca}^{2+}\right]_{\mathrm{o}}$ on fluorescence emission in one of 44 cells. (B) The elevations of $\left[\mathrm{Ca}^{2+}\right]_{\mathrm{i}}$ induced by $\left[\mathrm{Ca}^{2+}\right]_{\mathrm{o}}$ could be mimicked by one calcium-sensing receptor activator (spermidine) but not by $\mathrm{Gd}^{3+}$. (C) In addition to elevations of $\left[\mathrm{Ca}^{2+}\right]_{\mathrm{i}},\left[\mathrm{Ca}^{2+}\right]_{\circ}$ and spermidine, but not $\mathrm{Gd}^{3+}$, also produced transient reductions in $\left[\mathrm{Ca}^{2+}\right]_{\mathrm{i}}$. (D) The effects of $\left[\mathrm{Ca}^{2+}\right]_{\mathrm{o}}$ on maximal elevations of $\left[\mathrm{Ca}^{2+}\right]_{\mathrm{i}}$ were not modulated by the large-conductance calcium-activated potassium channel inhibitor iberiotoxin (iberio; $100 \mathrm{nM}$ ), nor by the voltage-gated potassium channel blocker TEA (5 mM). (E) These potassium channels blockers had no effect upon the acute decreases in $\left[\mathrm{Ca}^{2+}\right]_{i}$ elicited by $\left[\mathrm{Ca}^{2+}\right]_{\mathrm{o}}$. ** Significant difference at $P<0.01$; ***significant difference at 0.001 . Although data in (B)-(E) show mean \pm S.E.M. maximum or minimum responses expressed as a fraction of vehicle response, the statistical analysis compares responses of ligand with responses to vehicle control using one-way ANOVA

D

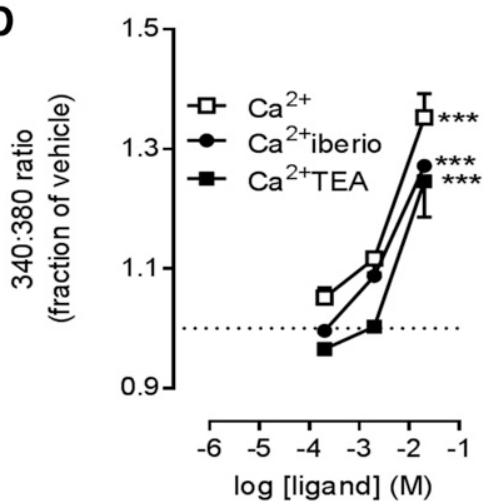

E

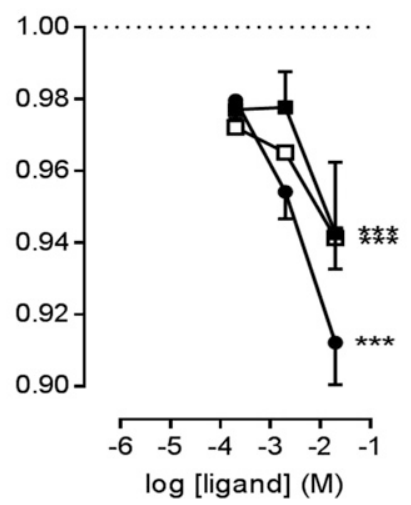
followed by post hoc Dunnett's test. Data were analyzed using 44-97 cells (from four to seven replicate experiments) and expressed as a fraction of cell vehicle control. 
A
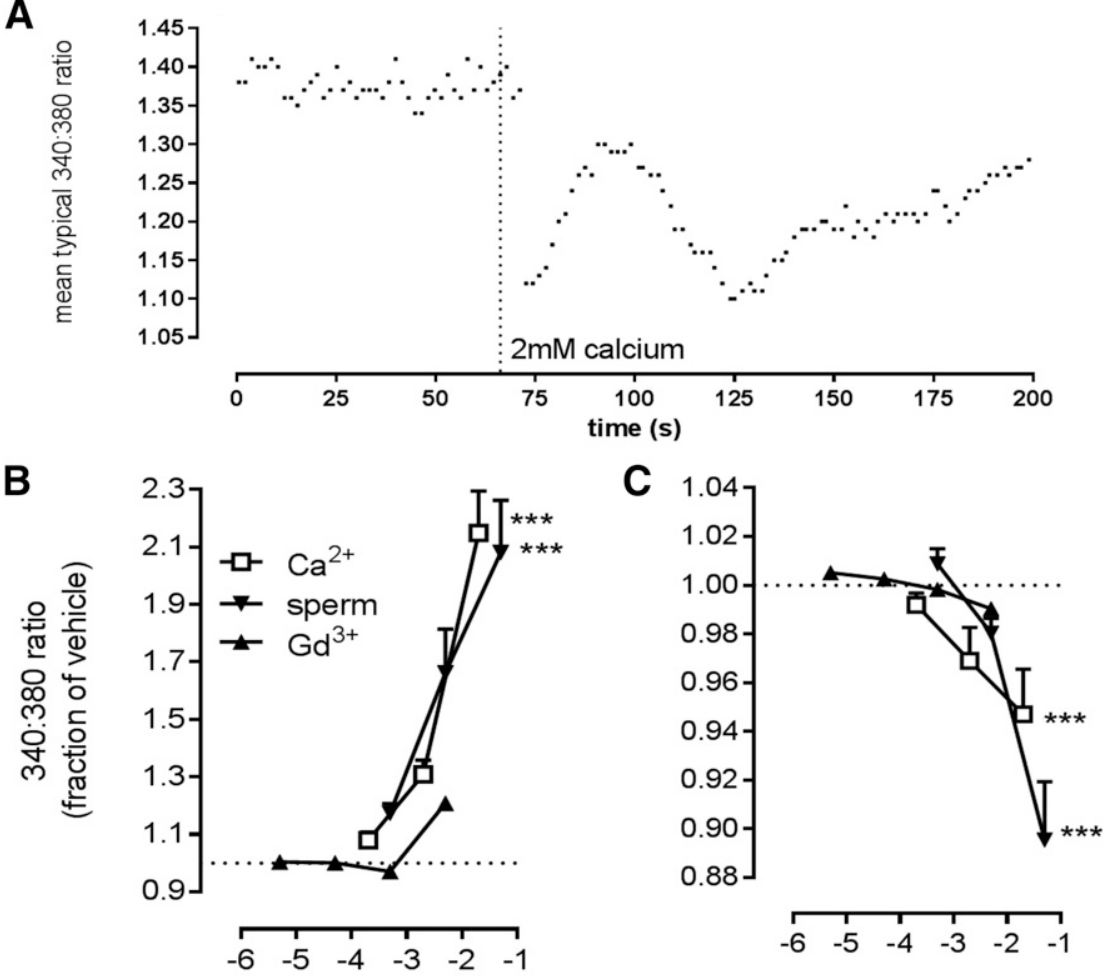

Fig. 4. Effects of $\left[\mathrm{Ca}^{2+}\right]_{o}$ on $\left[\mathrm{Ca}^{2+}\right]_{i}$ in FURA-2 AM-loaded NHMC podocyte-like cells. (A) Typical effect of $2 \mathrm{mM}$ $\left[\mathrm{Ca}^{2+}\right]_{\mathrm{o}}$ on fluorescence emission in one of 72 cells (six separate experiments). (B) The elevations of $\left[\mathrm{Ca}^{2+}\right]_{\mathrm{i}}$ induced by $\left[\mathrm{Ca}^{2+}\right]_{0}$ could be mimicked by one calciumsensing receptor activator [spermidine (sperm)] but not by $\mathrm{Gd}^{3+}$. (C) In addition to elevations of $\left[\mathrm{Ca}^{2+}\right]_{\mathrm{i}}$ $\left[\mathrm{Ca}^{2+}\right]_{\mathrm{o}}$ and spermidine, but not $\mathrm{Gd}^{3+}$, also produced transient reductions in $\left[\mathrm{Ca}^{2+}\right]_{i}$. (D) The effects of $\left[\mathrm{Ca}^{2+}\right]_{\mathrm{o}}$ on maximal elevations of $\left[\mathrm{Ca}^{2+}\right]_{i}$ were not modulated by the large-conductance calcium-activated potassium channel inhibitor iberiotoxin (iberio; $100 \mathrm{nM}$ ), the voltage-gated potassium channel blocker TEA ( $5 \mathrm{mM})$, or the focal adhesion kinase inhibitor PF562271 (PF; $10 \mathrm{nM}$ ). (E) Both potassium channel blockers as well as the focal adhesion kinase inhibitor reversed the acute decreases in $\left[\mathrm{Ca}^{2+}\right]_{\mathrm{i}}$ elicited by $\left[\mathrm{Ca}^{2+}\right]_{0}$. *** Significant differences $(P<0.001)$. Although data in $(\mathrm{B})-(\mathrm{E})$ show mean \pm S.E.M. maximum or minimum responses expressed as a fraction of vehicle response, the statistical analysis compares responses of ligand with responses to vehicle control using one-way ANOVA followed by post hoc Dunnett's test. Data were analyzed using 53-107 cells (from four to seven replicate experiments) and expressed as a fraction of cell vehicle control.
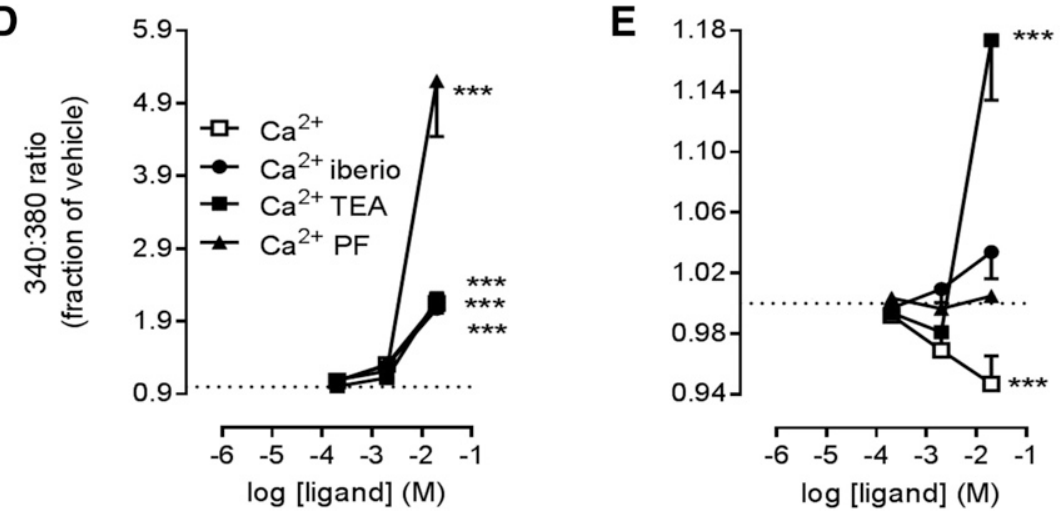

\section{Results}

\section{iPS Cell-Derived Podocyte-Like Cells Express Podocyte Markers}

Differentiation generated cultures containing around 30\%$50 \%$ cells with podocyte-like morphology, i.e., large flat cells with irregular borders. To qualitatively confirm the success of the directed differentiation, pluripotent stem cell-derived podocyte-like cells were immunolabeled with antibodies for the podocyte markers WT-1 and podocin (Song et al., 2012). At day 20 of differentiation, iPS-derived podocyte-like cells were immunolabeled for both WT-1 and podocin (Fig. 2). This expression was consistent with that observed in HIPs (Fig. 2).

Resting $\mathbf{C a}^{2+}$. Following loading with FURA-2 AM, average resting calcium was found to be significantly higher in AS1 and AS2 than in NHMC podocyte-like cells: 92 (95\% confidence interval: 68,126$)$ and 90 (95\% confidence interval: 75,108$)$ versus 55 (95\% confidence interval: 44,69 ) $\mathrm{nM}$, respectively (one-way ANOVA of $\log _{10}$ resting calcium with post hoc Tukey's test, $n=5-9$ biologic replicates using
44-63 individual cells). Podocyte-like cells were identified in culture as having a podocyte-like cell morphology (see Materials and Methods). These cells were generally quiescent with occasional spontaneous calcium transients (not shown).

\section{Responses to Extracellular Calcium: HIPs}

In calcium-free HEPES buffer, extracellular calcium $\left(\left[\mathrm{Ca}^{2+}\right]_{0}\right)$, the orthosteric ligand for the calcium-sensing receptor, elicited concentration-dependent changes in $\left[\mathrm{Ca}^{2+}\right]_{\mathrm{i}}$. These changes were evident as an acute depression of $\left[\mathrm{Ca}^{2+}\right]_{i}$ preceding an elevation; Fig. 3A shows a typical response to $2 \mathrm{mM}\left[\mathrm{Ca}^{2+}\right]_{0}$. Compared with vehicle control, $\left[\mathrm{Ca}^{2+}\right]_{\mathrm{o}}$ elicited both significant decreases and increases in $\left[\mathrm{Ca}^{2+}\right]_{\mathrm{i}}(P<0.05$, one-way ANOVA with post hoc Dunnett's test, $n=31$ cells from five replicate experiments; Fig. 3, B and C). We then assessed effects on $\left[\mathrm{Ca}^{2+}\right]_{i}$ of two other activators of the calciumsensing receptor, the polyamine spermidine and the trivalent cation gadolinium $\left(\mathrm{Gd}^{3+}\right)$. Spermidine, but not $\mathrm{Gd}^{3+}$, elicited both concentration-dependent decreases and increases in $\left[\mathrm{Ca}^{2+}\right]_{i}$ (Fig. 3, B and C). 
A

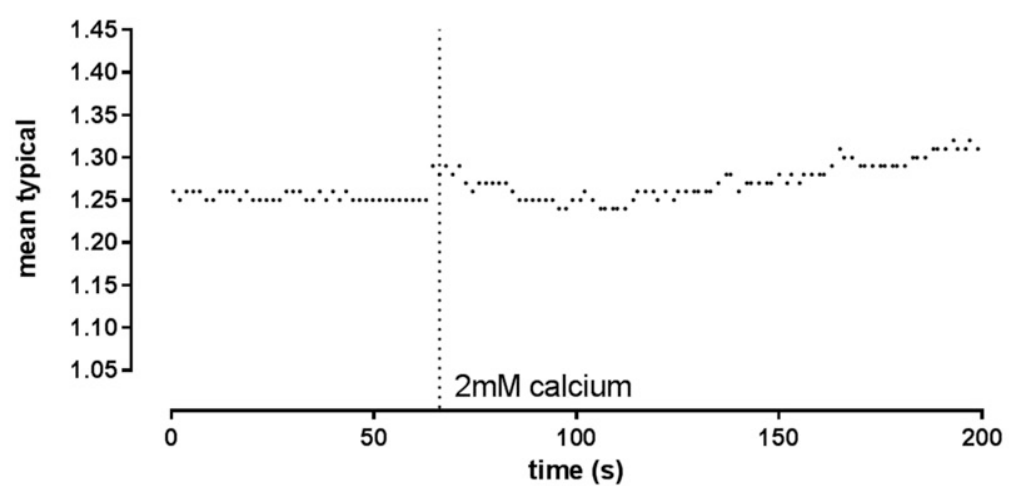

B

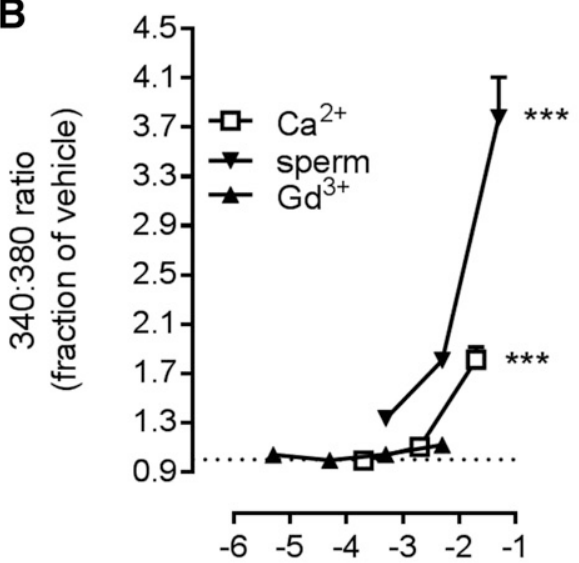

C

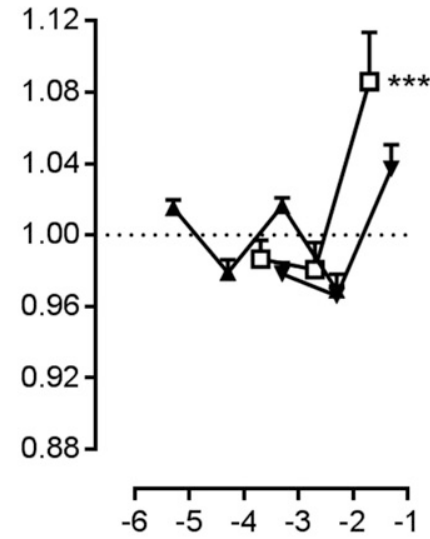

D

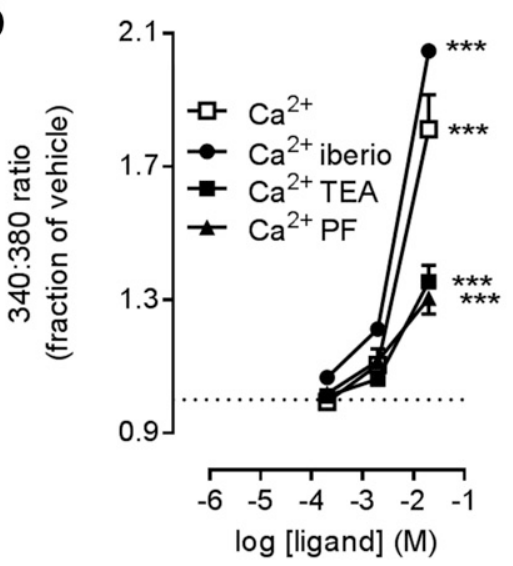

E

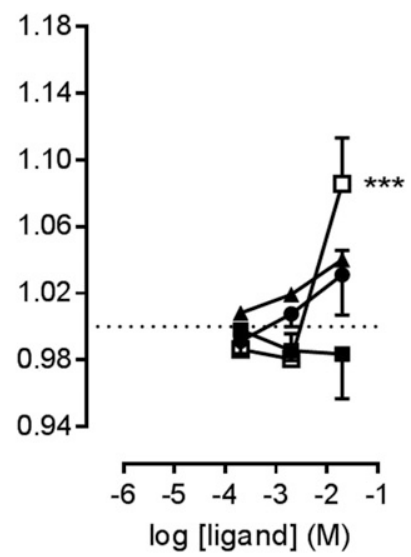

Fig. 5. Effects of $\left[\mathrm{Ca}^{2+}\right]_{o}$ on $\left[\mathrm{Ca}^{2+}\right]_{\mathrm{i}}$ in FURA-2 AM-loaded Alport syndrome patient-derived podocyte-like cells (AS1). (A) Typical effect of $2 \mathrm{mM}\left[\mathrm{Ca}^{2+}\right]_{\mathrm{o}}$ on fluorescence emission in one of 31 cells (five separate experiments). (B) The elevations of $\left[\mathrm{Ca}^{2+}\right]_{\mathrm{i}}$ induced by $\left[\mathrm{Ca}^{2+}\right]_{0}$ could be mimicked by one calcium-sensing receptor activator [spermidine (sperm)] but not by $\mathrm{Gd}^{3+}$. (C) Spermidine, $\mathrm{Gd}^{3+}$, and $\left[\mathrm{Ca}^{2+}\right]_{0}$ did not show any transient reduction of $\left[\mathrm{Ca}^{2+}\right]_{\mathrm{i}}$ prior to elevation. (D) The effects of $\left[\mathrm{Ca}^{2+}\right]_{\mathrm{o}}$ on maximal elevations of $\left[\mathrm{Ca}^{2+}\right]_{i}$ were not modulated by the large-conductance calcium-activated potassium channel inhibitor iberiotoxin (iberio; $100 \mathrm{nM}$ ), the voltage-gated potassium channel blocker TEA $(5 \mathrm{mM})$, or the focal adhesion kinase inhibitor PF562271 (PF; $10 \mathrm{nM}$ ). (E) The presence of the potassium channel blockers or $\mathrm{PF}$ did not promote the appearance of acute decreases in $\left[\mathrm{Ca}^{2+}\right]_{\mathrm{i}}$ elicited by $\left[\mathrm{Ca}^{2+}\right]_{\mathrm{o}}$. *** Significant differences $(P<$ 0.001, one-way ANOVA followed by post hoc Dunnett's test). Data were analyzed using 31-103 cells (from five to seven replicate experiments) and expressed as a fraction of cell vehicle control.
Given the relationship between calcium-sensing receptors and KCNMA1 channels (Vysotskaya et al., 2014), we explored the possibility that KCNMA1 channels might be responsible for the reductions in $\left[\mathrm{Ca}^{2+}\right]_{\mathrm{i}}$ that preceded elevations. Therefore, we incubated podocyte-like cells with the KCNMA1 channel inhibitor iberiotoxin (100 nM), as well as the less specific voltage-gated potassium channel blocker TEA ( $5 \mathrm{mM})$, prior to the addition of $\left[\mathrm{Ca}^{2+}\right]_{0}$. Neither iberiotoxin nor TEA affected the maximal elevations or inhibitions of $\left[\mathrm{Ca}^{2+}\right]_{\mathrm{i}}$ in response to $\left[\mathrm{Ca}^{2+}\right]_{\mathrm{o}}$ (Fig. 3, D and E).

\section{Responses to Extracellular Calcium: NHMC Podocyte-Like Cells}

In calcium-free HEPES buffer, $\left[\mathrm{Ca}^{2+}\right]_{\mathrm{o}}$ also elicited changes in $\left[\mathrm{Ca}^{2+}\right]_{\mathrm{i}}$ in NHMC podocyte-like cells. These changes were evident in a rapid decrease followed by a rapid elevation of
$\left[\mathrm{Ca}^{2+}\right]_{\mathrm{i}}(n=72$ cells from six replicate experiments; Figure 4, panel A shows a typical response to $2 \mathrm{mM}\left[\mathrm{Ca}^{2+}\right]_{\mathrm{o}}$ ). As with the HIPs, spermidine, but not $\mathrm{Gd}^{3+}$, produced both elevations and inhibitions of $\left[\mathrm{Ca}^{2+}\right]_{\mathrm{i}}$ (Fig. $4, \mathrm{~B}$ and $\mathrm{C}$ ).

Both iberiotoxin $(100 \mathrm{nM})$ and TEA $(5 \mathrm{mM})$ had no effect on $\left[\mathrm{Ca}^{2+}\right]_{0}$-induced elevations of $\left[\mathrm{Ca}^{2+}\right]_{\mathrm{i}}$ (Fig. 4D), but both ligands prevented the acute decreases in $\left[\mathrm{Ca}^{2+}\right]_{\mathrm{i}}$ (Fig. $4 \mathrm{E}$ ) in response to $\left[\mathrm{Ca}^{2+}\right]_{0}$, indicating that the acute reductions were due to KCNMA1 channel activity. These channels are known to be modulated by focal adhesion kinase (Rezzonico et al., 2003), so we incubated cells with the selective focal adhesion kinase inhibitor PF562271 (10 nM) before the addition of $\left[\mathrm{Ca}^{2+}\right]_{\mathrm{o}}$. This kinase inhibitor increased responses to $\left[\mathrm{Ca}^{2+}\right]_{\mathrm{o}}$ and prevented acute reductions in $\left[\mathrm{Ca}^{2+}\right]_{\mathrm{i}}$ (Fig. 4, D and E), possibly indicating an interaction between focal adhesion kinase and KCNMA1 channels in NHMC podocyte-like cells. 
A

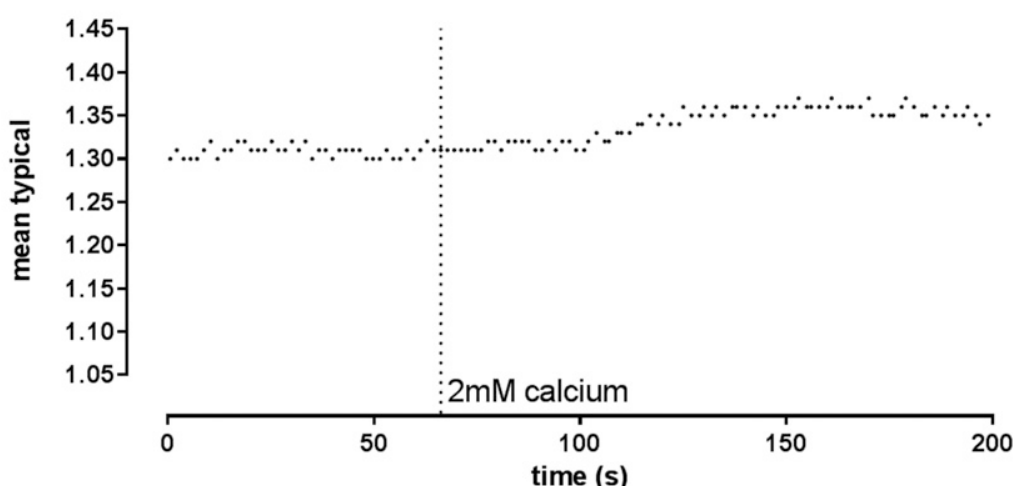

B

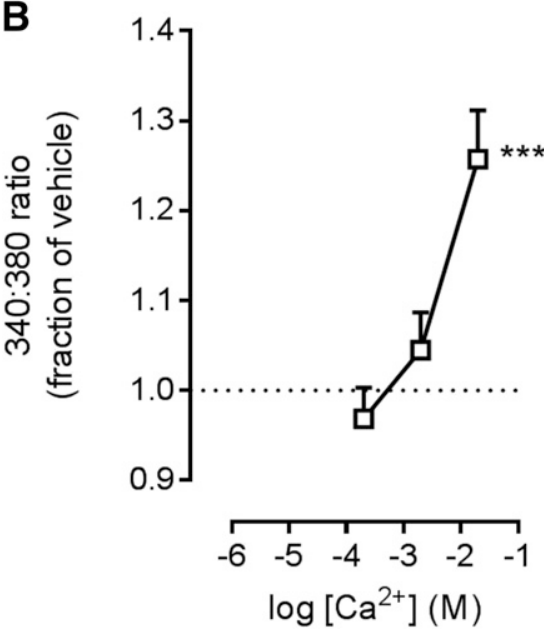

C

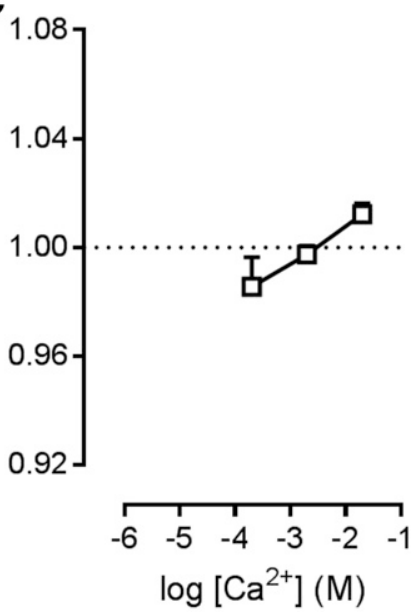

Fig. 6. Effects of $\left[\mathrm{Ca}^{2+}\right]_{o}$ on $\left[\mathrm{Ca}^{2+}\right]_{\mathrm{i}}$ in FURA-2 AM-loaded Alport syndrome patient-derived podocyte-like cells (AS2). (A) Typical effect of $2 \mathrm{mM}\left[\mathrm{Ca}^{2+}\right]_{o}$ on fluorescence emission in one of 47 cells (five separate experiments). The elevations of $\left[\mathrm{Ca}^{2+}\right]_{\mathrm{i}}$ induced by $\left[\mathrm{Ca}^{2+}\right]_{\mathrm{o}}(\mathrm{B})$ were not preceded by acute decreases in $\left[\mathrm{Ca}^{2+}\right]_{\mathrm{i}}(\mathrm{C})$. $* * *$ Significant differences $(P<0.001$, one-way ANOVA followed by post hoc Dunnett's test). Data are expressed as a fraction of cell vehicle controls.

\section{Responses to Extracellular Calcium: AS1 Podocyte-Like Cells}

In contrast to both HIPs and NHMC podocyte-like cells, AS1 podocyte-like cells responded to $\left[\mathrm{Ca}^{2+}\right]_{0}$ only with elevations of $\left[\mathrm{Ca}^{2+}\right]_{\mathrm{i}}(n=33$ cells from five replicate experiments). Figure 5A shows a typical response to $2 \mathrm{mM}\left[\mathrm{Ca}^{2+}\right]_{0}$. Spermidine, but not $\mathrm{Gd}^{3+}$, was an effective elevator of $\left[\mathrm{Ca}^{2+}\right]_{i}$ (Fig. $5 \mathrm{~B})$, but neither spermidine nor $\left[\mathrm{Ca}^{2+}\right]_{\mathrm{o}}$ produced reductions in $\left[\mathrm{Ca}^{2+}\right]_{\mathrm{i}}$ (Fig. 5C). TEA (5 mM), iberiotoxin (100 nM), and PF562271 (10 nM) did not uniformly modulate elevations of $\left[\mathrm{Ca}^{2+}\right]_{\mathrm{i}}$ in $\mathrm{AS} 1$ podocyte-like cells $(P<0.01$, one-way ANOVA with post hoc Dunnett's; $n=33$ values from five replicate experiments; Fig. 5D). TEA, iberiotoxin, and PF562271 did not promote the appearance of an acute reduction in intracellular calcium (Fig. 5E).

\section{Responses to Extracellular Calcium: AS2 Podocyte-Like Cells}

The AS2 podocyte-like cell responses to $\left[\mathrm{Ca}^{2+}\right]_{\mathrm{o}}$ were similar to the AS1 cell line, with concentration-dependent elevations but no acute decreases in $\left[\mathrm{Ca}^{2+}\right]_{\mathrm{i}}$ (Fig. 6).

\section{Large Conductance Calcium-Activated Potassium Channel Activity}

Given the role of KCNMA1 channels in podocyte function (Tao et al., 2016) and our own evidence of an effect, we further investigated the possibility that these channels were functional only in NHMC podocytes. The KCNMA1 channel opener NS1619 (1-10 $\mu \mathrm{M})$ elicited concentration-dependent reductions in basal calcium in both NHMC and HIP, but not AS1 podocyte-like cells (Fig. 7).

\section{Responses to Angiotensin II}

We next assessed whether another G-protein-coupled receptor, the angiotensin II receptor, could elicit both elevations and inhibitions of $\left[\mathrm{Ca}^{2+}\right]_{\mathrm{i}}$. Although angiotensin II elicited robust elevations of intracellular calcium in NHMC, HIP, and

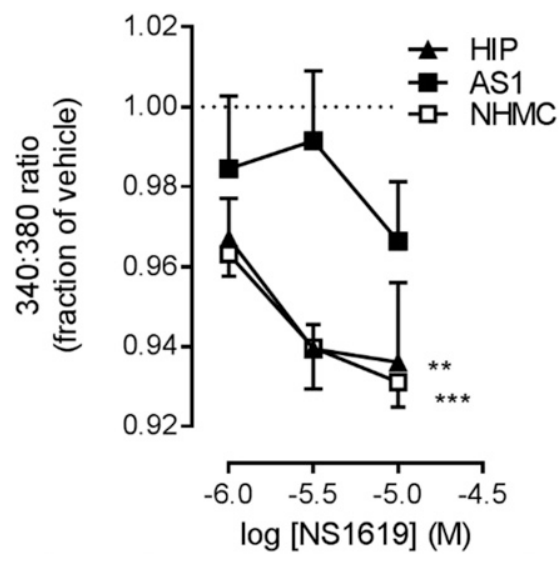

Fig. 7. Effects of a KCNMA1 channel opener, NS1619 $(1-10 \mu \mathrm{M})$, on intracellular calcium. NS1619 promoted concentration-dependent decreases in $\left[\mathrm{Ca}^{2+}\right]_{\mathrm{i}}$ in NHMC and HIP, but not AS1 podocyte-like cells. **Significant differences at $P<0.01$; ***significant differences at $P<0.001$; one-way ANOVA followed by post hoc Dunnett's test $[n=129$ (NHMC), 48 (HIP), and 81 (AS1) cells from seven, five, and five replicate experiments]. 
A

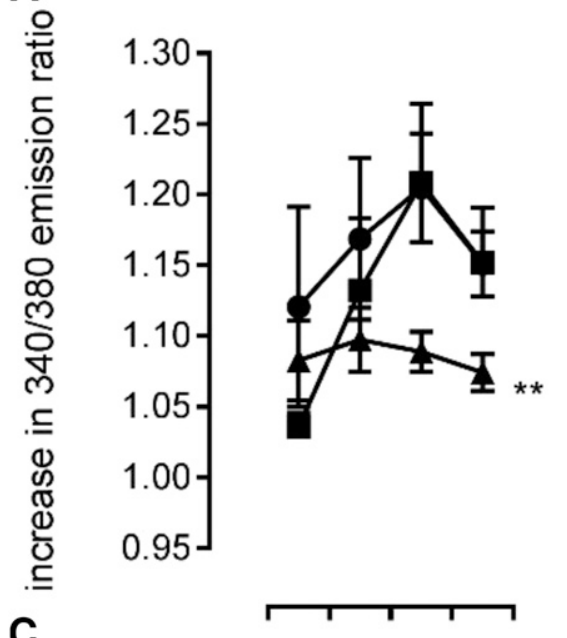

C

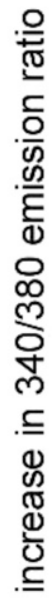

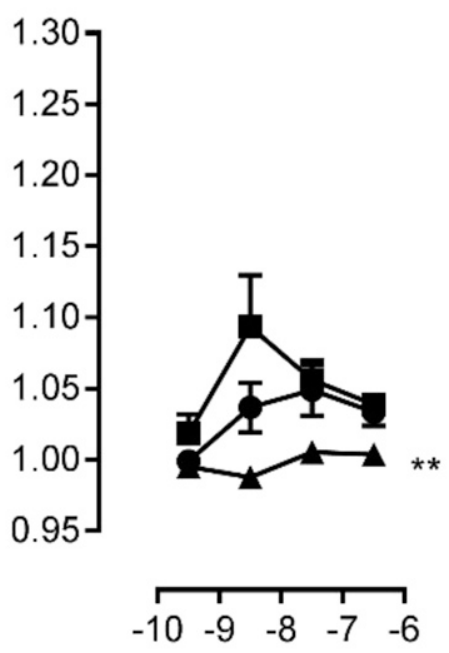

angiotensin II $(\log M)$
B
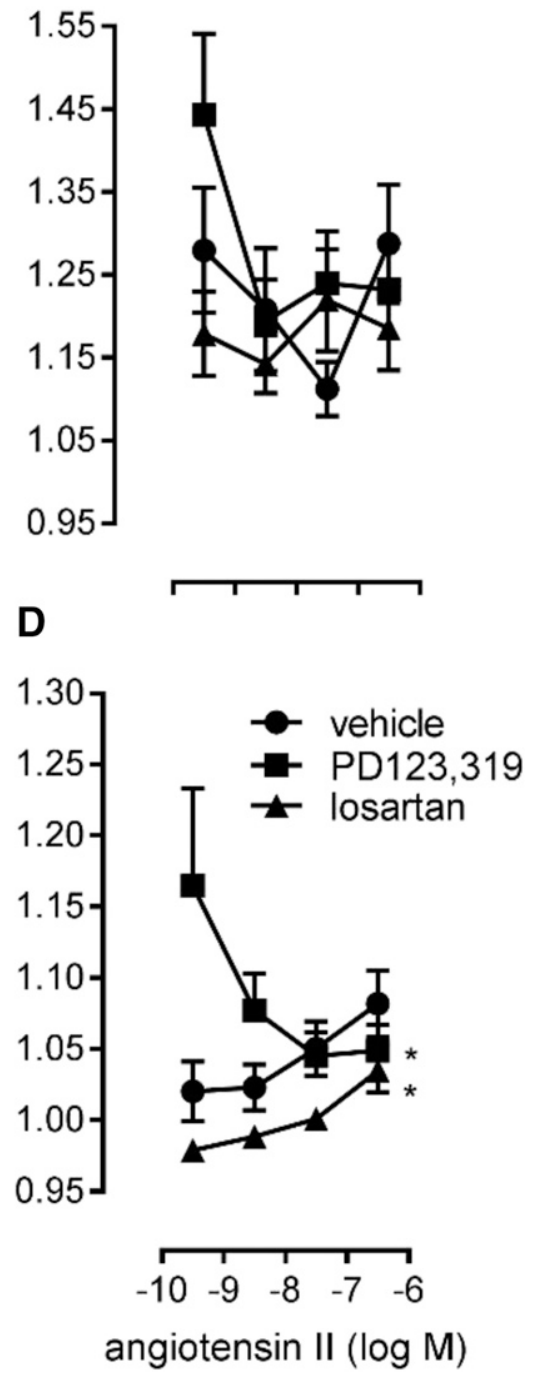

Fig. 8. The effects of losartan and PD123,319 (both at $1 \mu \mathrm{M})$ upon angiotensin II concentration-response effects in podocyte-like cells. Responses to NHMC (A), HIP (B), AS1 (C), and AS2 (D) podocyte-like cells. Responses of the three pluripotent stem cell-derived lines could be uniformly blocked by the angiotensin II receptor 1a ntagonist, losartan. *Significant differences at $P<0.05$; ** significant differences at $P<0.01$; one-way ANOVA, $n=29-38$ (NHMC), 30-38 (HIP), 34-49 (AS1), and 42-71 podocyte-like cells from four replicate experiments.
AS1 and weak responses in AS2 podocyte-like cells, we rarely saw any evidence of concentration dependence or acute decreases in intracellular calcium prior to elevations (not shown). However, responses to angiotensin II ( $0.3-300 \mathrm{nM})$ were robustly blocked by the angiotensin 1 receptor antagonist losartan $(1 \mu \mathrm{M})$ but not by the angiotensin 2 receptor antagonist PD123,319 (3[2,13,18-tris(2-amino-2-oxoethyl)-12,17-bis(3-amino-3-oxopropyl)3-[3-(2-hydroxypropylamino)-3-oxopropyl]-3,5,8,8,13,15,18,19octamethyl-1,2,5,6,7,10,12,17-octahydrocorrin-7-yl]propanamide, $1 \mu \mathrm{M}$ ) in all groups tested (Fig. 8).

qPCR and Immunolabeling. Since our data indicated the absence of functional KCNMA1 channels in AS patient-derived podocyte-like cells, we undertook qPCR and immunolabeling studies to identify whether transcript and protein for this receptor were present. We found largely equivalent levels of KCNMA1 transcript in AS1, but significantly reduced transcript $(P<0.05$, one-way ANOVA with post hoc Dunnett's test) in immortalized podocyte-like cells [expressed as a fraction of NHMC podocyte-like cell values: $1.29 \pm 0.34(N=3)$ for AS1 and $0.18 \pm 0.13(N=2)$ for HIP]. Nonetheless, immunolabeling showed evidence of KCNMA1 protein in all three cell lines tested (Fig. 9 shows typical labeling). We then tested the theory that replating AS1 podocyte-like cells onto decellularized plates of NHMC podocyte-like cells could restore channel function.

\section{Effects of Replating AS Podocyte-Like Cells onto Decellularized Plates that Had Contained NHMC Podocyte- Like Cells}

Following decellularization, plates were devoid of any sign of cells or cellular debris (not shown). AS1 podocyte-like cells cultivated upon plates that once contained NHMC podocytelike cells responded to lower concentrations of extracellular calcium with acute reductions of $\left[\mathrm{Ca}^{2+}\right]_{\mathrm{i}}$ that were not evident in AS1 podocytes replated onto decellularized AS1 podocyte plates $(P<0.001$, two-way ANOVA with post hoc Dunnett's test; Fig. 10). The acute reductions in intracellular calcium could be inhibited by TEA ( 5 mM; Fig. 10).

\section{Discussion}

In this study, we compared the activities of podocyte-like cells derived from AS patients; a healthy individual; and a commonly used, immortalized podocyte cell line. Consistent 

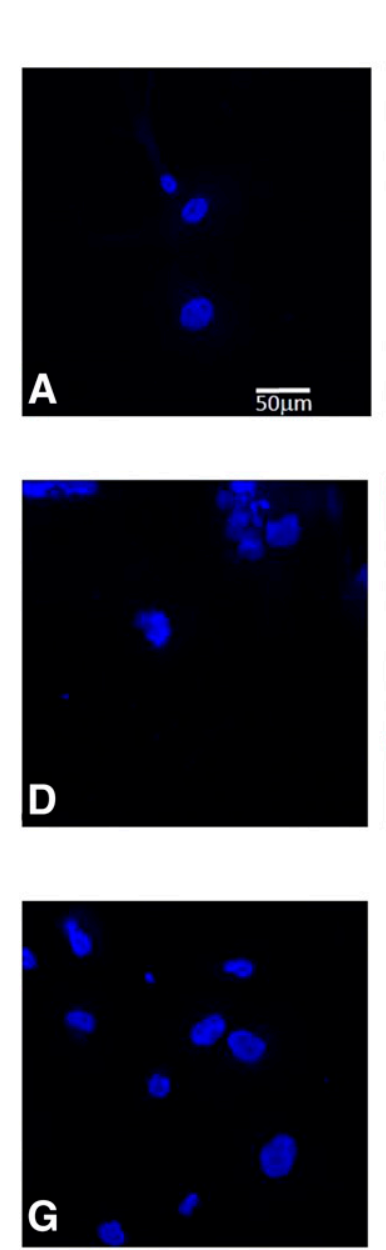
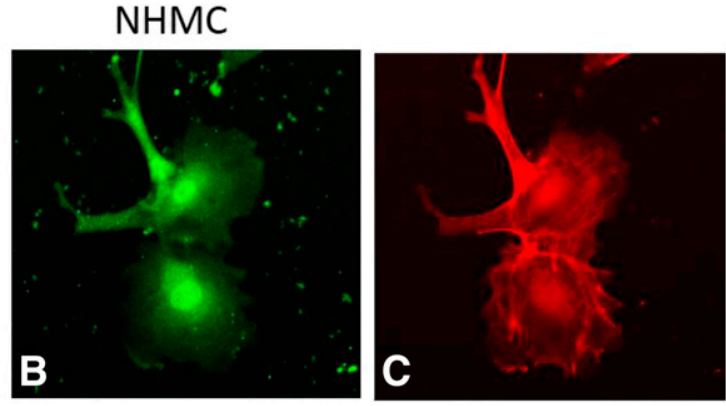

AS1
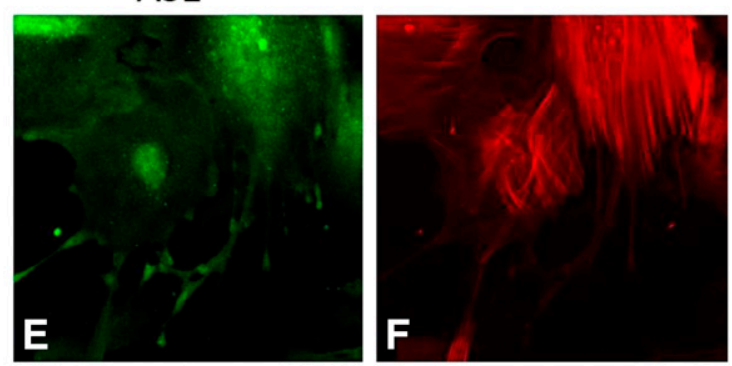

HIP
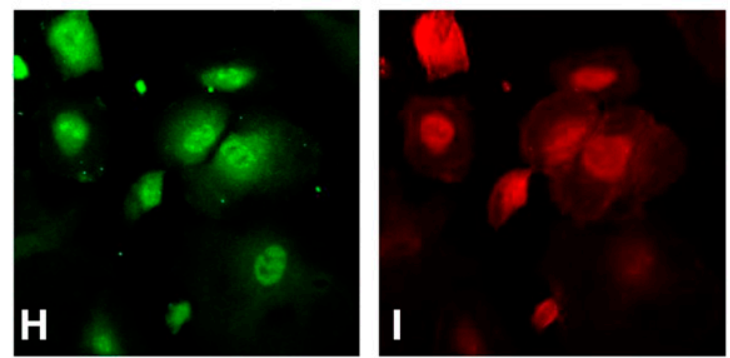

Fig. 9. Immunolabeling of iPS-derived NHMC and AS1 podocyte-like cells, as well as HIPs. DAPI (A), antiKCNMA1 (B), and phalloidin (C) labeling of NHMC podocyte-like cells. DAPI (D), anti-KCNMA1 (E), and phalloidin (F) labeling of AS1 podocyte-like cells. DAPI (G), anti-KCNMA1 (H), and phalloidin (I) labeling of HIPs. Scale bar, $50 \mu \mathrm{m}$. with our previous work (Song et al., 2011, 2012), the iPS cells used for this study showed expression of markers commonly used to identify podocytes: WT-1 and podocin. We then investigated whether AS patient-derived podocyte-like cells showed any discernible functional phenotype associated with the regulation of intracellular calcium, a critical regulator of function and survival in many cell types (van Empel and De Windt, 2004; Mattson, 2007; Oh et al., 2011). Podocyte-like cells were largely quiescent with infrequent spontaneous elevations of intracellular calcium. Resting $\left[\mathrm{Ca}^{2+}\right]_{\mathrm{i}}$ in both AS1 and AS2 podocyte-like cells ( $\sim 90 \mathrm{nM})$ was significantly greater than in NHMC podocyte-like cells ( $~ 55 \mathrm{nM})$. However, these values lie within previously reported values in human primary [113 \pm $22 \mathrm{nM}$ (Foster et al., 2003)] as well as human immortalized [146 $\pm 76 \mathrm{nM}$ (Ardaillou et al., 1996), $102 \pm 35 \mathrm{nM}$ (Foster et al., 2003)] and mouse immortalized podocyte-like cells [49 \pm $11 \mathrm{nM}$ (Huber et al., 1998), $82 \pm 12 \mathrm{nM}$ (Fischer et al., 2002)]. The variability of these data may be attributable to different assay methods and/or the presence of the spontaneous calcium fluctuations. That our assay shows significantly higher $\left[\mathrm{Ca}^{2+}\right]_{\mathrm{i}}$ in the AS podocyte-like cells may indicate some difference in calcium-handling capability.

We next determined whether the podocyte-like cell cultures showed differences in response to two G-protein-coupled receptors that have profound effects on podocyte function and survival: the CaSR and angiotensin II receptors. The CaSR belongs to the family C G-protein-coupled receptors; it is expressed throughout the body, especially the thyroid and parathyroid glands, kidney, bone, and brain (Brown, 1991; Brown and Macleod, 2001). Although widely distributed within the kidney (Riccardi and Brown, 2010), it is highly localized at the endoplasmic reticulum and the cell plasma membrane, especially at or close to podocyte slit diaphragms (Oh et al., 2011). This receptor plays a pivotal role in podocyte survival in subtotal nephrectomized rats (Ogata et al., 2003), and more recently, Oh et al. (2011) suggested that positive allosteric

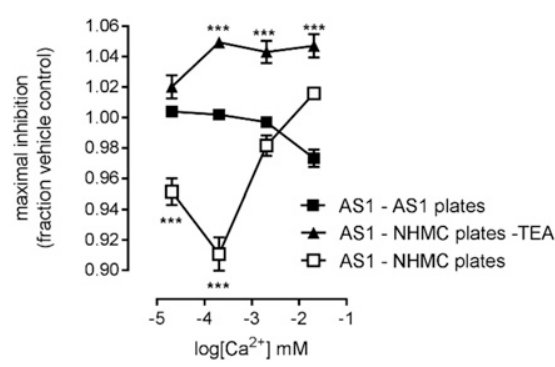

Fig. 10. Effects of replating AS1 podocyte-like cells back onto (decellularized) plates that had contained either AS1 or NHMC podocyte-like cells. AS1 cells replated onto NHMC plates responded to low concentrations of extracellular calcium with acute reductions in intracellular calcium, an effect that could be blocked by the addition of TEA $(5 \mathrm{mM})$. *** Significant differences at $P<0.001$ (two-way ANOVA with post hoc Dunnett's test). Data are expressed as a fraction of vehicle control in 25-56 cells from four replicate experiments. 
modulators (activators) of the CaSR limit antibiotic-induced podocyte damage via phosphorylated extracellular signalregulated kinase-mediated antiapoptotic and cytoskeletonstabilizing effects.

In response to the orthosteric activator of the CaSR, extracellular calcium, all podocyte-like cells showed elevations of $\left[\mathrm{Ca}^{2+}\right]_{i}$. We then tested two other ligands known to activate the calciumsensing receptor: gadolinium (Brown et al., 1993) and spermidine (Quinn et al., 1997). Gadolinium was ineffective across all cell lines tested; however, this lack of effect should be viewed with caution since $\mathrm{Gd}^{3+}$ has been shown to suppress receptoractivated TRP and ORAI [calcium release-activated calcium channel protein 1 (Malasics et al., 2010; Bouron et al., 2015; $\mathrm{Xu}$ et al., 2015)] activity. In contrast, the polyamine spermidine was an effective modulator of $\left[\mathrm{Ca}^{2+}\right]_{\mathrm{i}}$. Prior to elevations of intracellular calcium, we noted that both spermidine and $\left[\mathrm{Ca}^{2+}\right]_{\mathrm{o}}$ elicited a transient decrease in $\left[\mathrm{Ca}^{2+}\right]_{\mathrm{i}}$ in HIPs and NHMCs, but not AS podocyte-like cells. One of the most striking aspects of responses to spermidine in the four cell "lines" was the inconsistency of response. Although the morphology of the podocyte-like cells was consistent, particularly across the induced pluripotent stem cell-derived lines, the responses to extracellular calcium and spermidine were not. Thus, whereas extracellular calcium robustly increased intracellular calcium in NHMC podocyte-like cells, responses in HIP, AS1, and AS2 were greatly reduced. More curious perhaps was the observation that responses to spermidine were relatively consistent in AS1 and NHMC. Whether this effect relates to differences in calciumsensing receptor mutations, function, or expression, or more generic differences in cell lines is currently unknown. Consistent with this inconsistency, modulators of potassium channels produced little change in extracellular calcium-induced elevations of intracellular calcium in HIP and NHMC, whereas TEA appeared to produce a truncated response in AS1 podocytelike cells. Similarly, focal adhesion kinase inhibition produced a marked increase in extracellular calcium-induced maximal response in NHMC podocyte-like cells but a profound decrease in AS1 podocyte-like cells. At present, we believe that these disparate effects may result from differing states of tonic channel or kinase activity within each cell line. Perhaps of more significance is the idea that our observations raise questions about the suitability of single cell lines as exemplars of cell function. Although much is made of isogenic control modifications for induced pluripotent stem cell-derived cells, our observations indicate that caution must be observed in conclusions based upon single cell line experiments since any one of these cell lines may not be representative of broader aspects of "typical" physiologic behavior.

Since elevations of intracellular calcium can activate KCNMA1 channels (Tao et al., 2016), we assessed whether blockers of this channel, iberiotoxin and TEA (Singh et al., 2012), could inhibit transient decreases in $\left[\mathrm{Ca}^{2+}\right]_{\mathrm{i}}$. In NHMC podocyte-like cells, but not HIPs, the reductions of intracellular calcium were blocked by both iberiotoxin and TEA. The insensitivity of the immortalized podocyte-like cells to KCNMA1 blockers may indicate that this channel was either not present or functional, or that other calcium-activated potassium channels were capable of masking its activity. In a second effort to establish whether this channel was present, we assessed effects of the KCNMA1 channel opener NS1619 (Debska et al., 2003). NHMC and HIP, but not AS1 podocyte-like cells, showed decreases in intracellular calcium in response to NS1619, indicating the presence of KCNMA1 channels. To confirm the presence of these channels, we assessed AS1, NHMC, and HIP cultures for KCNMA1 channel mRNA. Surprisingly, we found this transcript to be universally expressed, with little difference in expression in AS1 and NHMC cultures. To ascertain whether the channel protein was present, we used immunolabeling and found the channel present in all cell lines, particularly in regions around the periphery of AS1 and NHMC podocyte-like cells. Given the presence of transcript and immunolabeled protein, we conclude that AS1 podocyte-like cells possess KCNMA1 channels, but they are not functional. The absence of functional KCNMA1 channels may have ramifications for podocyte survival since KCNMA1 channels are significant regulators of activity in podocytes and other cell types. In podocytes, KCNMA1 channels localize with nephrin and may regulate podocyte activity in response to stretching (Morton et al., 2004), although more complex interactions involving synaptopodin, Rho, and cytoskeletal proteins are also likely (Kim et al., 2010). In other cell types, KCNMA1 activation can protect cardiomyoblast cells from hypoxia/reperfusion damage (Fretwell and Dickenson, 2011) and reduce shock-induced reductions in vascular reactivity $(\mathrm{Hu}$ et al., 2014). KCNMA1 channel activity can also facilitate prostate cancer cell growth possibly through an association with $\alpha \mathrm{v} \beta 3$ integrin and focal adhesion kinase (Du et al., 2016). Although the absence of potassium channel function may explain the elevated intracellular calcium in AS1 (and AS2) podocyte-like cells, the mechanism underlying this effect was not immediately clear. Interestingly, in HIPs, iberiotoxin and TEA did not block the acute reductions in $\left[\mathrm{Ca}^{2+}\right]_{\mathrm{i}}$, but NS1619 showed an effect and qPCR indicated the presence, albeit at relatively low levels, of KCNMA1 transcript. At present, we speculate that KCNMA1 channels are present on these cells but may be present with additional TEA- and iberiotoxin-insensitive small-conductance calcium-activated potassium channels (Sah, 1996). Whether this makes these cells a better or worse in vitro model of podocyte function than pluripotent stem cell-derived podocyte-like cells is unclear.

There is evidence linking the integrin-linked focal adhesion kinase (So et al., 2011), the related kinase Pyk2 (Ling et al., 2004), as well as src (Yang et al., 2010) with the modulation of KCNMA1 channel activity in other cell types, so we speculated that collagen gene mutations in AS podocyte-like cells impacted upon integrin signaling. To investigate this idea, we assessed the influence of the selective focal adhesion kinase inhibitor PF562271 upon transient decreases in $\left[\mathrm{Ca}^{2+}\right]_{\mathrm{i}}$ and found it to abolish the acute reduction in intracellular calcium in NHMC podocyte-like cells. Although these data indicate some form of relationship between integrin signaling, focal adhesion kinase, and potassium channel signaling in podocytes, much more work is needed to identify the specific mechanisms underlying interaction.

We investigated whether another G-protein-coupled receptor known to modulate podocyte activity, the angiotensin II receptor (Nitschke et al., 2000; Hsu et al., 2008; Ilatovskaya et al., 2014), also showed acute decreases in intracellular calcium prior to elevations. Consistent with the idea that angiotensin II interacts with TRPC6 channels to elevate intracellular calcium (llatovskaya et al., 2014), angiotensin II elevated, without acute decreases, intracellular calcium at all concentrations tested. That these responses were predominantly blocked by the angiotensin II receptor antagonist losartan indicates a major role of the angiotensin II type 1 receptor in regulating acute elevations of 
intracellular calcium, a finding consistent with that reported for rat podocytes (Henger et al., 1997). As calcium, but not angiotensin II, promoted acute reductions in intracellular calcium, we believe that this may indicate specific coupling of G-protein-coupled receptors to potassium channels in podocytes.

The extracellular matrix plays a significant role in regulating cell and tissue function, and many studies have used decellularized tissue matrices to regulate the growth and survival of a number of different cell types, from hepatocytes (Lorvellec et al., 2017) to cardiomyocytes (Eitan et al., 2010). A smaller body of literature also indicates that two-dimensional cultures can generate their own matrix which, after decellularization, can be applied to new culture vessels (Decaris et al., 2012) or used as a substrate for reseeding (Pham et al., 2008). Since our PCR evidence indicated that KCNMA1 channels were present, but not functional, in AS1 podocyte-like cells, we tested the idea that replating AS1 podocyte-like cells onto surfaces once occupied by NHMCs could help restore channel activity. Following plating upon decellularized NHMC plates, we observed a small but significant reduction in $\left[\mathrm{Ca}^{2+}\right]_{\mathrm{i}}$ in $\mathrm{AS} 1$ podocyte-like cells following the addition of extracellular calcium. This effect was not evident in AS1 cells seeded onto decellularized AS1 plates. That this effect was also blocked by TEA indicated an effect through potassium channels.

Given the findings that: 1) inhibition of FAK blocked the transient reduction in intracellular calcium in response to extracellular calcium, and 2) replating of AS1 podocyte-like cells upon NHMC decellularized plates promoted a TEAsensitive reduction of intracellular calcium, we suggest that the KCNMA1 channels require appropriate integrin-FAK signaling for function. Although we show that calcium-sensing receptor activating ligands produce fundamentally different effects in immortalized, non-AS, and AS patient-derived podocyte-like cells, possibly through changes in KCNMA1 channel function, we must acknowledge the limitations of the current approach. The first of those limitations is that we showed differences in some aspects of podocyte-like cell function using data from a limited sample size: two patientderived, one control-derived, and one immortalized cell line. The second potential limitation is that, although our podocytelike cells possessed the morphologic and immunocytochemical profile of podocytes, in vitro studies may not truly show the functional properties of podocytes in situ. Despite these limitations, our studies demonstrate that induced pluripotent stem cell-derived podocyte-like cells may represent a useful system for basic mechanistic and pharmacological studies of heritable kidney disease.

\section{Authorship Contributions}

Participated in research design: Haynes.

Conducted experiments: Haynes, Selby, Vandekolk, Abad, Ho, Lieuw, Saini, Fisher.

Contributed new reagents or analytic tools: Savige.

Performed data analysis: Haynes.

Wrote or contributed to the writing of the manuscript: Haynes, Leach, Ricardo.

\section{References}

Ardaillou N, Blaise V, Costenbader K, Vassitch Y, and Ardaillou R (1996) Characterization of a B2-bradykinin receptor in human glomerular podocytes. Am $J$ Physiol 271:F754-F761.

Baiguera S, Del Gaudio C, Lucatelli E, Kuevda E, Boieri M, Mazzanti B, Bianco A and Macchiarini P (2014) Electrospun gelatin scaffolds incorporating rat decellularized brain extracellular matrix for neural tissue engineering. Biomaterials 35: 1205-1214.
Barker DF, Hostikka SL, Zhou J, Chow LT, Oliphant AR, Gerken SC, Gregory MC, Skolnick MH, Atkin CL, and Tryggvason K (1990) Identification of mutations in the COL4A5 collagen gene in Alport syndrome. Science 248:1224-1227.

Blattner SM and Kretzler M (2005) Integrin-linked kinase in renal disease: connecting cell-matrix interaction to the cytoskeleton. Curr Opin Nephrol Hypertens 14:404-410.

Bouron A, Kiselyov K, and Oberwinkler J (2015) Permeation, regulation and control of expression of TRP channels by trace metal ions. Pflugers Arch 467:1143-1164. Brown EM (1991) Extracellular $\mathrm{Ca}^{2+}$ sensing, regulation of parathyroid cell function, and role of $\mathrm{Ca}^{2+}$ and other ions as extracellular (first) messengers. Physiol Rev 71: $371-411$.

Brown EM, Gamba G, Riccardi D, Lombardi M, Butters R, Kifor O, Sun A, Hediger MA, Lytton J, and Hebert SC (1993) Cloning and characterization of an extracellular $\mathrm{Ca}(2+)$-sensing receptor from bovine parathyroid. Nature 366:575-580.

Brown EM and MacLeod RJ (2001) Extracellular calcium sensing and extracellular calcium signaling. Physiol Rev 81:239-297.

Cook AL, Frydenberg M, and Haynes JM (2002) Protein kinase G activation of K (ATP) channels in human-cultured prostatic stromal cells. Cell Signal 14: 1023-1029.

Cosgrove D (2012) Glomerular pathology in Alport syndrome: a molecular perspective. Pediatr Nephrol 27:885-890.

Debska G, Kicinska A, Dobrucki J, Dworakowska B, Nurowska E, Skalska J, Dolowy K, and Szewczyk A (2003) Large-conductance K+ channel openers NS1619 and NS004 as inhibitors of mitochondrial function in glioma cells. Biochem Pharmacol 65:1827-1834.

Decaris ML, Mojadedi A, Bhat A, and Leach JK (2012) Transferable cell-secreted extracellular matrices enhance osteogenic differentiation. Acta Biomater 8: $744-752$.

Du C, Zheng Z, Li D, Chen L, Li N, Yi X, Yang Y, Guo F, Liu W, Xie X, et al. (2016) BKCa promotes growth and metastasis of prostate cancer through facilitating the coupling between $\alpha \mathrm{v} \beta 3$ integrin and FAK. Oncotarget 7:40174-40188.

Eitan Y, Sarig U, Dahan N, and Machluf M (2010) Acellular cardiac extracellular matrix as a scaffold for tissue engineering: in vitro cell support, remodeling, and biocompatibility. Tissue Eng Part C Methods 16:671-683.

Feingold J, Bois E, Chompret A, Broyer M, Gubler MC, and Grünfeld JP (1985) Genetic heterogeneity of Alport syndrome. Kidney Int 27:672-677.

Fischer KG, Huber TB, Henger A, Fink E, Schwertfeger E, Rump LC, and Pavenstädt $\mathrm{H}$ (2002) Eluate derived by extracorporal antibody-based immunoadsorption elevates the cytosolic $\mathrm{Ca} 2+$ concentration in podocytes via $\mathrm{B} 2$ kinin receptors. Kidney Blood Press Res 25:384-393.

Foster RR, Hole R, Anderson K, Satchell SC, Coward RJ, Mathieson PW, Gillatt DA, Saleem MA, Bates DO, and Harper SJ (2003) Functional evidence that vascular endothelial growth factor may act as an autocrine factor on human podocytes. Am J Physiol Renal Physiol 284:F1263-F1273.

Fretwell L and Dickenson JM (2011) Role of large-conductance $\mathrm{Ca}^{2}+$-activated $\mathrm{K}+$ channels in adenosine $\mathrm{A}_{1}$ receptor-mediated pharmacological postconditioning in H9c2 cells. Can J Physiol Pharmacol 89:24-30.

Greka A and Mundel P (2012) Cell biology and pathology of podocytes. Annu Rev Physiol 74:299-323.

Groden DL, Guan Z, and Stokes BT (1991) Determination of Fura-2 dissociation constants following adjustment of the apparent Ca-EGTA association constant for temperature and ionic strength. Cell Calcium 12:279-287.

Grynkiewicz G, Poenie M, and Tsien RY (1985) A new generation of $\mathrm{Ca} 2+$ in dicators with greatly improved fluorescence properties. J Biol Chem $\mathbf{2 6 0}$ 3440-3450.

Henger A, Huber T, Fischer KG, Nitschke R, Mundel P, Schollmeyer P, Greger R, and Pavenstädt H (1997) Angiotensin II increases the cytosolic calcium activity in rat podocytes in culture. Kidney Int 52:687-693.

Hsu HH, Hoffmann S, Endlich N, Velic A, Schwab A, Weide T, Schlatter E, and Pavenstädt H (2008) Mechanisms of angiotensin II signaling on cytoskeleton of podocytes. J Mol Med (Berl) 86:1379-1394.

Hu Y, Yang G, Xiao X, Liu L, and Li T (2014) Bkca opener, NS1619 pretreatment protects against shock-induced vascular hyporeactivity through PDZ-Rho GEFRhoA-Rho kinase pathway in rats. J Trauma Acute Care Surg 76:394-401.

Huber TB, Gloy J, Henger A, Schollmeyer P, Greger R, Mundel P, and Pavenstädt H (1998) Catecholamines modulate podocyte function. J Am Soc Nephrol 9:335-345. Hudson BG, Tryggvason K, Sundaramoorthy M, and Neilson EG (2003) Alport's syndrome, Goodpasture's syndrome, and type IV collagen. $N$ Engl J Med 348: $2543-2556$

Ilatovskaya DV, Palygin O, Chubinskiy-Nadezhdin V, Negulyaev YA, Ma R, Birnbaumer L, and Staruschenko A (2014) Angiotensin II has acute effects on TRPC6 channels in podocytes of freshly isolated glomeruli. Kidney Int 86:506-514.

Ishida Y and Nagata K (2011) Hsp47 as a collagen-specific molecular chaperone Methods Enzymol 499:167-182.

Kabgani N, Grigoleit T, Schulte K, Sechi A, Sauer-Lehnen S, Tag C, Boor P, Kuppe C, Warsow G, Schordan S, et al. (2012) Primary cultures of glomerular parietal epithelial cells or podocytes with proven origin. PLoS One 7:e34907.

Kim EY, Suh JM, Chiu YH, and Dryer SE (2010) Regulation of podocyte BK(Ca) channels by synaptopodin, Rho, and actin microfilaments. Am J Physiol Renal Physiol 299:F594-F604.

Lang RJ, Haynes JM, Kelly J, Johnson J, Greenhalgh J, O'brien C, Mulholland EM, Baker L, Munsie M, and Pouton CW (2004) Electrical and neurotransmitter activity of mature neurons derived from mouse embryonic stem cells by Sox-1 lineage selection and directed differentiation. Eur J Neurosci 20:3209-3221.

Liebau MC, Lang D, Böhm J, Endlich N, Bek MJ, Witherden I, Mathieson PW, Saleem MA, Pavenstädt H, and Fischer KG (2006) Functional expression of the renin-angiotensin system in human podocytes. Am J Physiol Renal Physiol 290: F710-F719.

Ling S, Sheng JZ, and Braun AP (2004) The calcium-dependent activity of large-conductance, calcium-activated $\mathrm{K}+$ channels is enhanced by Pyk2- and 
Hck-induced tyrosine phosphorylation. Am J Physiol Cell Physiol 287: C698-C706.

Lorvellec M, Scottoni F, Crowley C, Fiadeiro R, Maghsoudlou P, Pellegata AF, Mazzacuva F, Gjinovci A, Lyne AM, Zulini J, et al. (2017) Mouse decellularised liver scaffold improves human embryonic and induced pluripotent stem cells differentiation into hepatocyte-like cells. PLoS One 12:e189586.

Malasics A, Boda D, Valiskó M, Henderson D, and Gillespie D (2010) Simulations of calcium channel block by trivalent cations: $\mathrm{Gd}(3+)$ competes with permeant ions for the selectivity filter. Biochim Biophys Acta 1798:2013-2021.

Mattson MP (2007) Calcium and neurodegeneration. Aging Cell 6:337-350.

Mochizuki T, Lemmink HH, Mariyama M, Antignac C, Gubler MC, Pirson Y, Verellen-Dumoulin C, Chan B, Schröder CH, Smeets HJ, et al. (1994) Identification of mutations in the alpha 3(IV) and alpha 4(IV) collagen genes in autosomal recessive Alport syndrome. Nat Genet 8:77-81.

Morissette Martin P, Shridhar A, Yu C, Brown C, and Flynn LE (2018) Decellularized adipose tissue scaffolds for soft tissue regeneration and adipose-derived stem/ stromal cell delivery. Methods Mol Biol 1773:53-71.

Morton MJ, Hutchinson K, Mathieson PW, Witherden IR, Saleem MA, and Hunter M (2004) Human podocytes possess a stretch-sensitive, Ca2+-activated $\mathrm{K}+$ channel: potential implications for the control of glomerular filtration. J Am Soc Nephrol 15: 2981-2987.

Mundel P and Kriz W (1995) Structure and function of podocytes: an update. Anat Embryol (Berl) 192:385-397.

Nitschke R, Henger A, Ricken S, Gloy J, Müller V, Greger R, and Pavenstädt H (2000) Angiotensin II increases the intracellular calcium activity in podocytes of the intact glomerulus. Kidney Int 57:41-49.

Obeidová H, Merta M, Reiterová J, Maixnerová D, Stekrová J, Rysavá R, and Tesar V (2006) Genetic basis of nephrotic syndrome--review. Prague Med Rep 107:5-16.

Ogata H, Ritz E, Odoni G, Amann K, and Orth SR (2003) Beneficial effects of calcimimetics on progression of renal failure and cardiovascular risk factors. $J$ Am Soc Nephrol 14:959-967.

Oh J, Beckmann J, Bloch J, Hettgen V, Mueller J, Li L, Hoemme M, Gross ML, Penzel R, Mundel P, et al. (2011) Stimulation of the calcium-sensing receptor stabilizes the podocyte cytoskeleton, improves cell survival, and reduces toxininduced glomerulosclerosis. Kidney Int 80:483-492.

Olesen SP, Munch E, Moldt P, and Drejer J (1994) Selective activation of $\mathrm{Ca}(2+)$ dependent $\mathrm{K}+$ channels by novel benzimidazolone. Eur J Pharmacol 251:53-59.

Pham QP, Kasper FK, Scott Baggett L, Raphael RM, Jansen JA, and Mikos AG (2008) The influence of an in vitro generated bone-like extracellular matrix on osteoblastic gene expression of marrow stromal cells. Biomaterials 29:2729-2739.

Pieri M, Stefanou C, Zaravinos A, Erguler K, Stylianou K, Lapathitis G, Karaiskos C, Savva I, Paraskeva R, Dweep H, et al. (2014) Evidence for activation of the unfolded protein response in collagen IV nephropathies. J Am Soc Nephrol 25: 260-275.

Preston A and Haynes JM (2003) Alpha 1-adrenoceptor effects mediated by protein kinase C alpha in human cultured prostatic stromal cells. Br J Pharmacol 138:218-224.

Quinn SJ, Ye CP, Diaz R, Kifor O, Bai M, Vassilev P, and Brown E (1997) The Ca2+sensing receptor: a target for polyamines. Am J Physiol 273:C1315-C1323.

Reiser J, Kriz W, Kretzler M, and Mundel P (2000) The glomerular slit diaphragm is a modified adherens junction. J Am Soc Nephrol 11:1-8.

Rezzonico R, Cayatte C, Bourget-Ponzio I, Romey G, Belhacene N, Loubat A, Rocch S, Van Obberghen E, Girault JA, Rossi B, et al. (2003) Focal adhesion kinase
pp125FAK interacts with the large conductance calcium-activated hSlo potassium channel in human osteoblasts: potential role in mechanotransduction. J Bone Miner Res 18:1863-1871.

Riccardi D and Brown EM (2010) Physiology and pathophysiology of the calciumsensing receptor in the kidney. Am J Physiol Renal Physiol 298:F485-F499.

Roberts WG, Ung E, Whalen P, Cooper B, Hulford C, Autry C, Richter D, Emerson E, Lin J, Kath J, et al. (2008) Antitumor activity and pharmacology of a selective foca adhesion kinase inhibitor, PF-562,271. Cancer Res 68:1935-1944

Sah P (1996) Ca(2+)-activated K+ currents in neurones: types, physiological roles and modulation. Trends Neurosci 19:150-154

Saleem MA, O'Hare MJ, Reiser J, Coward RJ, Inward CD, Farren T, Xing CY, Ni L Mathieson PW, and Mundel P (2002) A conditionally immortalized human podocyte cell line demonstrating nephrin and podocin expression. J Am Soc Nephrol 13: $630-638$

Shankland SJ, Pippin JW, Reiser J, and Mundel P (2007) Podocytes in culture: past, present, and future. Kidney Int 72:26-36.

Singh SK, O'Hara B, Talukder JR, and Rajendran VM (2012) Aldosterone induces active $\mathrm{K}^{+}$secretion by enhancing mucosal expression of Kcnn4c and Kcnma1 channels in rat distal colon. Am J Physiol Cell Physiol 302:C1353-C1360.

So EC, Wu KC, Liang CH, Chen JY, and Wu SN (2011) Evidence for activation of BK Ca channels by a known inhibitor of focal adhesion kinase, PF573228. Life Sci 89: $691-701$.

Song B, Niclis JC, Alikhan MA, Sakkal S, Sylvain A, Kerr PG, Laslett AL, Bernard CA, and Ricardo SD (2011) Generation of induced pluripotent stem cells from human kidney mesangial cells. J Am Soc Nephrol 22:1213-1220.

Song B, Smink AM, Jones CV, Callaghan JM, Firth SD, Bernard CA, Laslett AL, Kerr PG, and Ricardo SD (2012) The directed differentiation of human iPS cells into kidney podocytes. PLoS One 7:e46453.

Tao J, Lan Z, Wang Y, Hei H, Tian L, Pan W, Zhang X, and Peng W (2016) Largeconductance calcium-activated potassium channels in glomerulus: from cell signal integration to disease. Front Physiol 7:248

van Empel VP and De Windt LJ (2004) Myocyte hypertrophy and apoptosis: a balancing act. Cardiovasc Res 63:487-499.

Vysotskaya ZV, Moss CR II, Gilbert CA, Gabriel SA, and Gu Q (2014) Modulation of $\mathrm{BK}$ channel activities by calcium-sensing receptor in rat bronchopulmonary sensory neurons. Respir Physiol Neurobiol 203:35-44.

Watmuff B, Hartley BJ, Hunt CP, Fabb SA, Pouton CW, and Haynes JM (2015) Human pluripotent stem cell derived midbrain PITX3(eGFP/w) neurons: a versatile tool for pharmacological screening and neurodegenerative modeling. Front Cell Neurosci 9:104.

Xu YJ, Elimban V, and Dhalla NS (2015) Reduction of blood pressure by storeoperated calcium channel blockers. J Cell Mol Med 19:2763-2770.

Yang Y, Wu X, Gui P, Wu J, Sheng JZ, Ling S, Braun AP, Davis GE, and Davis MJ (2010) Alpha5beta1 integrin engagement increases large conductance, Ca2+-activated $\mathrm{K}+$ channel current and $\mathrm{Ca} 2+$ sensitivity through c-src-mediated channel phosphorylation. J Biol Chem 285:131-141.

Address correspondence to: John M. Haynes, Monash Institute of Pharmaceutical Sciences, Monash University, Victoria, Australia. E-mail: john.haynes@monash.edu 